\title{
EXPLORING THE USE OF ZIRCON GEOCHRONOLOGY AS AN INDICATOR OF LAURENTIDE ICE SHEET TILL PROVENANCE, INDIANA, U.S.A.
}

Christine M. Kassab ${ }^{1 *}$, Samantha L. Brickles ${ }^{1}$, Kathy J. Licht ${ }^{1}$, and G. William Monaghan ${ }^{2}$

\author{
${ }^{1}$ Department of Earth Sciences \\ Indiana University-Purdue University Indianapolis \\ 723 W Michigan St, SL118 \\ Indianapolis, IN 46202 \\ 2Indiana Geological Survey \\ 611 N. Walnut Grove \\ Bloomington, IN 47405 \\ *corresponding author (ckassab@iupui.edu; Tel: 317-278-1343)
}

This is the author's manuscript of the article published in final edited form as:

Kassab, C. M., Brickles, S. L., Licht, K. J., \& Monaghan, G. W. (2017). Exploring the use of zircon geochronology as an indicator of Laurentide Ice Sheet till provenance, Indiana, USA. Quaternary Research, 88(3), 525-536.

https://doi.org/10.1017/qua.2017.71 


\section{Abstract}

A pilot study was designed to evaluate the potential of zircon geochronology as a provenance indicator of till from the Lake Michigan, Saginaw, and Huron-Erie Lobes of the Laurentide Ice Sheet. Based on existing ice flow-path models, we hypothesized that till from each lobe would have different zircon age population distributions because the lobes originated from regions of the Canadian Shield with different bedrock ages. After correcting for zircon fertility, the majority of grains in all till samples are 1600-950 Ma, with $\sim 30 \%$ of ages $>2500 \mathrm{Ma}$. This similarity means that till from the three lobes cannot be clearly differentiated based on their zircon populations. The dominant ages found and the homogeneity of distributions in the till indicates a non-Shield source and instead reflect an origin from some combination of underlying till and sedimentary bedrock in the Great Lakes region. Even though the datasets are small, the tills have similarities to zircon distributions in Michigan Basin rocks. This implies that a substantial fraction of zircon in till was not transported long distances from the Canadian Shield. Although zircon ages are not distinct between tills, the method provides a novel application to understand Laurentide Ice Sheet glacial erosion and transport.

Keywords: U-Pb geochronology; Laurentide; ice sheet; glacial till; provenance

\section{Introduction}

Reconstructing ice flow paths is important for understanding and modeling past ice sheet behavior. The ability to determine ice flow paths is complicated however, in regions where glacial landforms indicating flow direction are absent or buried and moraine systems are complex (Mickelson et al., 1983; Colgan et al., 2003). Because many areas in the Great Lakes region lack well-defined glacial landforms that clearly indicate flow direction for the last glacial 
maximum (LGM), other methods must be employed. In particular, most of the glaciated region of central Indiana (Tipton till plain) lacks landforms indicating flow direction, therefore analysis of till provenance has been used for reconstructing past ice flow paths..

Local scale dispersal will result in till composition that reflects regional bedrock whereas continental scale dispersal $(100 \mathrm{~s} \mathrm{~km})$ results in tills with compositions that are more challenging to track back to bedrock sources (Clark, 1987). In an ideal system where ice flow direction remains constant, glacial debris concentration in ice decreases exponentially downstream from the bedrock source, dispersing the concentration of debris from the original bedrock source over local (kilometers) to continental scales (100s-1000s km) (Clark, 1987; Shilts, 1993; Boulton, 1996; Hooke et al., 2013; Larson and Mooers, 2004). The transport distance is controlled by a number of factors including till dynamics, sliding velocities, frictional resistances, basal debris concentration, and erosivity (Clark, 1987; Boulton, 1996; Larson and Mooers, 2004). In regions covered by continental ice sheets, it is generally thought that glacial debris is more likely to be transported at continental scales, resulting in till that reflects bedrock sources up to hundreds of kilometers away (e.g., Shilts, 1993; Clark, 1987; Boulton, 1996). Clark (1987) found that dispersal trains from Canadian-sourced ice carried basal debris for several hundred kilometers. However, other studies on continental ice sheet tills have documented much shorter transport distances. For instance, Larson and Mooers (2005), found that pigeonite concentrations in Ontario decreased exponentially within $10 \mathrm{~s} \mathrm{~km} \mathrm{downstream} \mathrm{of} \mathrm{the} \mathrm{source} \mathrm{rock.} \mathrm{Shorter}$ transport distances are a result of low sliding velocities, high frictional resistance, high basal debris concentration, and/or proximity to an ice divide (Clark, 1987; Boulton, 1996). Boulton (1996) found that the location of peak concentration may shift depending on glacial dynamics and the retreat rate. 
Ice flow-path reconstructions indicate that the ice lobes of the Southern Laurentide Ice Sheet extended >500 km from southern Canada to the Great Lakes region (Margold et al., 2015a, 2015b). The Great Lakes region is a complex system as it has been glaciated numerous times (e.g. Mickelson and Colgan, 2003; Curry et al., 2011; Syverson and Colgan, 2011) and flow paths may not have remained constant during advance and retreat within a glaciation. In addition, sediment can be entrained anywhere the basal conditions are suitable, resulting in spatial and temporal variability of entrainment over long flow paths (Alley et al., 1997). This may result in complex mixing of possible sediment sources (Prest et al., 2000).

Determining till provenance is one method that can be used to reconstruct past ice flow pathways (e.g., Gwyn and Dreimanis, 1979; Dworkin et al., 1985; Licht and Palmer, 2013). The provenance of tills in the Midwest has been studied using a variety of methods across pebbleand sand-size fractions. These studies of mineralogy and petrography link different ice lobes back to possible source areas (Anderson, 1957; Harrison, 1960; Bleuer, 1975; Gwyn and Dreimanis, 1979; Taylor and Faure, 1981; Dworkin et al., 1985; Karls, 2005; Coram, 2011). Different methodologies have yielded variable, sometimes conflicting, results. Using differences in the concentration and abundances (or absence) of heavy minerals in the fine-sand fraction, Gwyn and Driemanis (1979) and Dworkin et al. (1985) found that heavy mineral concentrations in tills were different between ice lobes in the upper Great Lakes (Lake Michigan Lobe, HuronErie Lobe, and Saginaw Lobe). Differences in the abundance of a few key heavy minerals, including clinopyroxene, garnet, epidote, and tremolite, were used to separate the ice lobes in Michigan and link them directly with specific bedrock provenances in the Canadian Shield. Using groupings of these heavy minerals, they showed that Huron-Erie Lobe till in Michigan was derived from a region east of Lake Huron while Saginaw Lobe and Lake Michigan Lobe tills were derived from a region north of Lake Huron. Similarly, Bleuer (1975) noted a distinct difference in the heavy mineral ratio of garnet to epidote in tills in west-central Indiana; Huron- 
Erie Lobe till has a higher garnet:epidote ratio than tills deposited by the Lake Michigan Lobe. Detrital magnetite composition in Huron-Erie Lobe till within eastern Indiana led Karls (2005) to infer that the most likely source for these tills incorporated felsic plutonic and mafic volcanic sources in central Canada, but the grains could be traced only to a rock type and not a specific source region.

In contrast to studies that identify a Canadian shield source for tills, Harrison (1960) reported high abundance of mineral and rock fragments of sedimentary rock origin in till collected in central Indiana. This important difference raises the question of how much of the sand-size mineralogy of till is locally derived and how much of it reflects long-distance transport from the Canadian Shield. Similar to Harrison (1960), clast counts from till in Michigan, Indiana, and Illinois show that, although a significant portion of the till consists of sedimentary rock $(>70 \%)$, only igneous pebbles were used to determine upstream sources in Canada (Anderson, 1957; Coram, 2011). The identification of similar rock types in moraines associated with different ice lobes in these studies may reflect reworking and incorporation of older till into younger deposits. Linking minerals to their source is often more difficult than linking rock fragments, because minerals could be derived from either primary (igneous) or secondary (sedimentary) sources.

Taylor and Faure (1981) were the first to report geochronological data to determine provenance in the Great Lakes region. They used $\mathrm{Rb}-\mathrm{Sr}$ ages of feldspar grains in till to trace Huron-Erie Lobe tills to upstream source regions They assumed that the feldspar grains were directly derived from igneous rocks of the Canadian Shield because most sedimentary rocks do not contain high percentages of feldspar. Because each sample contained a mixture of feldspar grains from source bedrock having different Rb-Sr ages (1070 Ma and $2700 \mathrm{Ma}$ ), the resulting 'ages' from the till represent a value that is proportional to the relative number of grains in each sample derived from the two source regions. The resulting ages did show an east-to-west 
increase from $1200 \mathrm{Ma}$ to $1800 \mathrm{Ma}$, in central Ohio to eastern Indiana, respectively. This reflects an increase in the abundance of grains derived from older igneous rocks north of Lake Huron in Canada. Because the Rb-Sr ages obtained through this method reflect the average age of this mixture, the feldspar grains cannot be directly linked to a specific source or region.

The success of utilizing detrital zircon U-Pb geochronology to constrain the provenance of glacial tills in Antarctica (e.g., Palmer et al., 2012; Licht and Palmer, 2013; Licht et al., 2014) led us to develop a pilot study to test the applicability of zircon ages as source indicators of glacial deposits in Indiana. We evaluated the idea that tills from each glacial lobe have a distinct detrital zircon age signature that can be traced to various igneous bodies in the Canadian Shield, the nearest primary sources of igneous zircons (Figure 1; Shaw et al., 2010; Margold et al., 2015a, 2015b). Igneous rocks of the Canadian Shield can broadly be characterized by age: >2500 Ma, 1700-1650 Ma, 1600-1300 Ma, and 1300-950 Ma (Figure 1). Based on the ice flow reconstructions, we hypothesized that the Huron-Erie Lobe would contain dominantly 1300-950 Ma detrital zircon ages, and the Lake Michigan Lobe would contain dominantly $>2500 \mathrm{Ma}$ zircons. Because the Saginaw Lobe originated over igneous bodies of both ages, the detrital zircons should record a mixture of ages.

\section{Geomorphic Setting}

Upwards of $200 \mathrm{~m}$ of glacial till covers the Great Lakes region, deposited as the Laurentide Ice Sheet advanced and retreated in the region over many glacial cycles (e.g. Wayne, 1956;

Mickelson and Colgan, 2003; Curry et al., 2011; Esch, 2011; Syverson and Colgan, 2011). Individual till units rarely exceed $5 \mathrm{~m}$ and in many places till sheets are separated by a paleosol or outwash deposit that marks distinct retreat and readvance episodes (e.g., Gooding, 1975; Hall and Anderson, 2000, 2001). The Huron-Erie Lobe, Saginaw Lobe, and Lake Michigan Lobe 
advanced over Indiana asynchronously during the last glaciation, reaching their maximum extent prior to $23{ }^{14} \mathrm{C}$ ka BP and retreating out of the region by $14{ }^{14} \mathrm{C}$ ka BP (Dyke et al., 2002; Glover et al., 2011). Ice flow reconstructions have the Lake Michigan Lobe flowing through Lake Michigan and extending into northwestern and west-central Indiana, the Saginaw Lobe flowing through central Michigan into northern Indiana, and the Huron-Erie Lobe flowing from Lake Huron and Lake Erie into northeastern Indiana, extending as far south as central Indiana (Figure 1; Leverett and Taylor, 1915; Mickelson and Colgan, 2003; Margold et al., 2015a). A series of distinct moraines outline the extent of ice advance in northern Indiana. However, in west-central Indiana, the lobe that deposited the uppermost till is ambiguous because much of the land is part of the low-relief Tipton till plain, lacking well-defined moraines (Colgan et al., 2003).

\section{Sample Sites and Methods}

Three sampling sites in this study were selected because of their unambiguous lobe association. They include the Valparaiso moraine of the Lake Michigan Lobe (LML), the Mississinewa moraine of the Huron-Erie Lobe (HEL), and the Packerton moraine of the Saginaw Lobe (SL). Most moraines were described and named prior to the availability of good topographical data and, therefore, may have been mischaracterized (Leverett and Taylor, 1915; Malott, 1922). However, we are confident that till at each of the three end-member sites represents sediment transported by a different lobe of the Laurentide Ice Sheet. We selected sample sites on flat, upland areas of moraines, away from drainages, and where Quaternary material is mapped as clayey Wisconsin-age (MIS 2) till (Figure 2). Because this is a pilot study, only one sampling site was selected for each glacial lobe. The samples may not be timeequivalent, but instead represent the some of the youngest deposits in Indiana associated with the retreat of each lobe. Because our primary interest was differentiating potential source areas for each glacial lobe and not how source areas changed over time, the depositional age of each 
till is not important. Tills near these sample locations have been described previously (e.g., Wayne and Thornbury, 1951; Wayne, 1965, 1967; Gooding, 1973). A fourth sample (UN) was purposefully collected from a location where the ice source was ambiguous; this sample came from Fountain County between the Crawfordsville moraine (associated with Huron-Erie Lobe) and Champaign moraine (associated with Lake Michigan Lobe) (Figure 2; Table 1; Fraser, 1993; Wayne, 1965). The UN sample is located in an area that was alternately covered by the Huron-Erie and Lake Michigan Lobes (Fraser, 1993), but it is not certain which lobe was the last to cover this specific area and the age of the moraines is unconstrained.

A sample of glacial till (10-50 cm depth) was collected for U-Pb provenance analysis at each site. The till was wet-sieved and the $63-250 \mu \mathrm{m}$ fraction isolated to extract detrital zircons. Standard gravimetric and magnetic separation techniques for zircon U-Pb analysis were used to isolate the zircon fraction. Zircon grains, both standards and unknowns, were mounted in epoxy pucks and polished to expose the grains. Standards used include Plesovice and FC-1 for age correction and NIST 612 was used for instrument calibration. Each sample was imaged with cathode luminescence to characterize grain shape and to aid in avoiding inclusions, cracks, or regions of zonation that may produce unreliable ages. Unknown zircon grains were dated by LA-ICPMS U-Pb methods in the Geoanalytical Lab at Washington State University using a New Wave Nd:YAG UV $213 \mathrm{~nm}$ laser coupled to a ThermoFinnigan Element 2 single-collector double-focusing magnetic sector following methods described in Gaschnig et al. (2013). Only those grains with $<10 \%$ discordance were retained for statistical analyses. Best ages were selected by using the ${ }^{206} \mathrm{~Pb} /{ }^{238} \mathrm{U}$ age for all grains younger than $1000 \mathrm{Ma}$ and the ${ }^{206} \mathrm{~Pb} /{ }^{207} \mathrm{~Pb}$ age for all grains older than 1000 Ma. Full results are included in the supplementary data.

Ages from each sample were broken down into the following ranges to simplify comparison between samples: >2500 Ma, 2500-2000 Ma, 2000-1800 Ma, 1800-1700 Ma, 1700-1600 Ma, 
1600-1300 Ma, 1300-950 Ma, and <950 Ma. These ranges are based on known geological events outlined in Whitmeyer and Karlstrom (2007). Analysis of the zircon ages was conducted using published statistical methods including the Kolmogorov-Smirnoff (K-S) test, degree of similarity, degree of overlap, and degree of likeness. Each method compares the four age populations to each other to calculate how alike (or different) they are. The K-S test is used to determine the probability that two samples were derived from different populations and is dependent on the maximum probability difference between two cumulative distribution function curves (Guynn and Gehrels, 2010). Samples having p values less than 0.05 indicate that it is likely that the two populations were derived from different sources. The degree of overlap and degree of similarity measure the degree to which two age probabilities overlap and whether the proportions of overlapping ages are similar, respectively. The closer the value is to 1 , the more alike the samples are (Gehrels, 2000; Satkoski et al., 2013). The degree of likeness calculates the percentage of sameness between two age distributions. The closer the value to $100 \%$, the more alike the samples are (Satkoski et al., 2013).

Based on the a priori assumption that zircon grains were derived from primary bedrock sources, age distributions were adjusted by taking into account the zircon fertility factor (ZFF). Previous work (e.g., Moecher et al., 2006; Dickinson, 2008) suggests that 1600-900 Ma zircons are much more prevalent in detrital assemblages than zircons of other ages owing to the higher zirconium content in the plutonic bedrock in North America. For most plutonic sources, the ZFF is approximately 1.0 , but for $1600-1300 \mathrm{Ma}$ and $1300-900$ Ma zircon grains, the ZFFs are 2.5 and 3.5, respectively (Dickinson, 2008). When adjusting the percentage of grains that fall within specific age ranges for the ZFF, the percentage of grains was interpreted as the number of grains out of 100 grains. This number was then divided by the ZFF values. This results in a lower number of grains within the 1600-1300 Ma and 1300-900 Ma age ranges, reducing the apparent $n=$ value. A new percentage of grains within each age range was then calculated by 
totaling up the number of grains within the sample after the ZFF was applied and dividing the number of grains adjusted for the ZFF within each age range by the new total number of grains. The ZFF adjusted dataset is strictly used for a comparison of percentage of grains that fall within a specific age range. All of the statistical analyses described in the previous paragraph were calculated using the original dataset of grain ages and associated errors.

\section{Results}

Cathode luminescence imagery of the zircon pucks illustrates that $>95 \%$ of the grains are rounded and lack well-defined prismatic tips (Figure 3). There is no age difference between rounded and non-rounded grains. A total of 426 detrital zircon grains were analyzed from the four samples, yielding ages that range from 3100-400 Ma (Figure 4). Eight age ranges (Table 2), based on known age ranges of igneous and metamorphic rocks upstream (Whitmeyer and Karlstrom, 2007), are used to group the zircon ages within each sample. The following percentages are based on the dataset prior to applying the ZFF. Greater than $70 \%$ of the grains in each sample fall between 1600-950 Ma, within two of the pre-selected ranges. The HEL sample has the greatest percentage of grains within this age range (84\%), and the UN sample has the least $(71 \%)$. Even though the majority of grains fall within this age range, the distribution of ages for each sample differs. HEL and UN have a bimodal distribution of ages within the 1600-950 Ma age range (Figure 4). The two age peaks which define the bimodal distribution, calculated using AgePick (University of Arizona Laserchron) are similar between these two samples, at $1445 \mathrm{Ma}$, and $1155 \mathrm{Ma}$. This difference is well beyond the measurement error of 10-20 Ma (Table 3). SL has a unimodal distribution and a broadly distributed set of grains 1600 $1300 \mathrm{Ma}$, whereas LML has three relatively equal age peaks (Figure 4). The youngest peak age is $1095 \mathrm{Ma}$ for the SL sample and $1105 \mathrm{Ma}$ for the LML sample, which are essentially indistinguishable given the analytical errors on measured values. The LML sample also has two 
other significant peaks at $1235 \mathrm{Ma}$ and $1450 \mathrm{Ma}$. This older peak is similar to the second peak in the HEL and UN samples. Approximately $10-20 \%$ of grains in all four samples are $>2500 \mathrm{Ma}$ with peak ages between 2710-2680Ma. The SL and UN samples also have a few grains scattered between 400-600 Ma; grains this age are not present in the HEL and LML samples. All four samples have a few grains scattered between $2500-1600 \mathrm{Ma}$, but only the LML and UN samples have enough grains with overlapping ages to produce peak ages, around $1850 \mathrm{Ma}$.

Applying the zircon fertility factor to the data set shifts the relative dominance of grains within the two main age ranges (1600-950 Ma and >2500 Ma). A zircon fertility factor of 3.5 for grains 1300-950 Ma, 2.5 for grains 1600-1300 Ma, and 1 for all other age ranges (Dickinson, 2008) results in a decrease in the percentage of grains $1600-1000$ Ma from $71-84 \%$ to $45-60 \%$ and increases the percentage of grains $>2500$ Ma from $12-18 \%$ to $20-40 \%$ (Table 2 ). This effectively decreases the height of the 1600-1000 Ma peaks, making them more comparable to those $>2500 \mathrm{Ma}$.

Four different statistical tests used to distinguish whether or not samples were derived from the same populations yield similar results. Each of these tests compares all measured zircon ages (unmodified by ZFF) between two samples at a time. Based on the results of the K-S test, the HEL, SL, and LML samples all have $p$ values $>0.05$, which supports the conclusion that they were not derived from different populations (Table 4). The three other statistical tests (overlap, similarity, likeness) also indicate that the three samples are not distinct from each other. All three samples have relatively high degrees of overlap $>0.725$ and degrees of similarity $>0.806$. The closer the value is to 1 , the higher the degree of overlap and similarity. The degree of likeness varies only from $71-76 \%$, which indicates that the samples are not very distinct.

\section{Discussion}


Detrital zircon geochronology of till is a promising technique to help determine past ice flow paths and identify regions of sediment entrainment by the Laurentide Ice Sheet. This technique, especially when used in combination with other provenance methods, can provide valuable information that reduces uncertainty in interpretations of the provenance of glacial sediments (see method review in Licht and Hemming, 2017). This pilot study represents the first attempt at applying the technique to Midwestern tills and, although it cannot be considered a comprehensive analysis because of the small number of samples, it serves as a starting point to evaluate the potential of the technique in this region. Below we discuss the likely origin of zircons in the till in an effort to understand the unexpected similarity between samples and then compare the provenance implications to other provenance methods.

\section{Origin of zircon grains}

Our study tested the hypothesis that the U-Pb detrital zircon ages in the till samples would be directly related to the upstream bedrock geology not covered by thick Quaternary deposits (i.e., derived from the Canadian Shield). Using this approach, along with LGM flow line reconstructions (Margold et al., 2015b), the LML sample was expected to be dominated by $>2500 \mathrm{Ma}$ age grains, the HEL sample dominated by 1300-950 Ma grains, and the SL sample containing a mixture of both age ranges. As described in the previous section, the measured detrital zircon ages do not support this hypothesis. The dominance of 1600--950 Ma ages in the LML lobe tills was particularly unexpected because igneous rocks $1600-950$ Ma are found only in the eastern part of Canada and are not in the probable flow path of Lake Michigan Lobe ice (Figure 1). Moreover, a low percentage of grains is derived from igneous rocks $>2500$ Ma for all three lobes. Bedrock of this age is primarily directly north and upstream of the Lake Michigan Lobe and not in the probable flow path of the other two lobes (Figure 1). The similar zircon age 
populations between samples and conflict with flow path reconstructions suggest that the detrital zircons may have been derived from a source other than Precambrian bedrock in the Canadian Shield. One alternative source is Paleozoic sedimentary rock within the Michigan Basin that contains zircon eroded from the Shield (Figure 5).

The Michigan Basin includes Cambrian to Jurassic age rocks deposited in marine and stream/floodplain settings that have a dominant paleocurrent direction from the north/northeast (Potter and Siever, 1956; Siever and Potter, 1956; Potter and Pryor, 1961; Shideler, 1969). The majority of clastic bedrock exposed in the basin is Devonian and younger, the youngest being of possible Jurassic age. Carbonate rocks are typically devoid of or have a very low abundance of zircons and shale is too fine grained for the size fraction we analyzed, so here we focus on sandstones as possible sources. Sandstones of the Pennsylvanian Saginaw and Mississippian Marshall Formations are primarily located in central Michigan. Outcrops of these formations are not common because they are buried under tens of meters of glacial deposits.

There are a few studies of $\mathrm{U}-\mathrm{Pb}$ ages of detrital zircon from Michigan Basin rocks that are located directly in the LGM flowline for the Saginaw Lobe (Figure 5; e.g., Dickinson et al., 2010; Boothroyd, 2012). Bedrock samples from these two studies yield broadly similar detrital zircon age populations as our till samples (Figure 4). The exact distribution of ages varies between each formation but, in general, $36-70 \%$ of grains are $1300-950 \mathrm{Ma}$ and $0-11 \%>2500 \mathrm{Ma}$ based on the original dataset (Dickinson et al., 2010; Boothroyd, 2012) (Supplementary Table 5). Accounting for ZFF, the distribution of ages $1300-950$ Ma decreases to $16-44 \%$ and slightly increases to $0-17 \%$ for grains $>2500$ Ma. Because paleocurrent direction is generally from the northeast for these formations, we make a simplifying assumption that the provenance signature is similar across the entire formation. There are a few notable differences between till we measured and these bedrock samples. In the till samples, only a few grains had ages that were $<950$ Ma while the bedrock samples contain 10-15\% grains <950 Ma. In addition, the till 
samples had $25-30 \%$ of grains $1600-1300 \mathrm{Ma}$, whereas the bedrock samples contain only $10-$ $15 \%$ grains of this age. Statistical comparison of the till and bedrock age distributions indicates there is a degree of similarity between the bedrock and till samples, but there is no exact match (Supplementary Table 6). Apart from the aforementioned differences, the overall similarity in zircon age distributions supports the idea that zircon grains in the till were at least partly derived from the underlying bedrock, rather than directly from the Shield, especially for the Lake Michigan Lobe till. Further studies of the detrital zircon populations in both Michigan Basin rocks and tills are needed to allow more robust comparisons.

The zircons in the till samples are nearly all rounded, with $<1 \%$ having retained a euhedral shape (Figure 3). The high degree of roundness suggests that the grains underwent transport, possibly through multiple cycles of sedimentary transport. Clast composition and sand mineralogy of tills associated with the three ice lobes suggest that sedimentary rocks, especially sandstone, make up a significant percentage of the total clast types (Anderson, 1957; Harrison, 1960; Coram, 2011). Of the two likely bedrock sources of zircons in the till, sandstone typically breaks down more rapidly than igneous clasts and, therefore, will contribute more zircons to the sand fraction of the till. Even though the upstream parts of the Lake Michigan and Huron-Erie Lobe catchments may have been located over different ages of igneous bedrock, the zircon age population observed in the tills indicates that zircons from other sources diluted the original zircon population. But, because a thick veneer of glacial till overlies most of the bedrock in Michigan, it may be more likely that the zircons are recycled from older till deposits, which may have been deposited by ice lobes that followed different paths than those of the latest LGM advance. Regardless of the source, bedrock or the underlying till, the samples contain an unexpected distribution of zircon ages, in particular the LML, which contains a surprisingly low proportion of $>2500$ Ma grains. 


\section{Comparison with previous methods}

Results from this study indicate that the ice lobes in the Great Lakes either did not follow currently accepted LGM ice flow paths or that tills deposited by the lobes were dominantly derived from Paleozoic bedrock underlying the Michigan Basin. We have no physical basis to suggest the flow paths are erroneous and, therefore, favor the latter interpretation. If this is true, any analyses, including mineralogy and geochronology, must consider a more complex history for these grains, which makes their use for long distance provenance and transport more challenging.

Previous provenance studies suggested that there is enough distinction in the till deposited by lobes covering the Midwest to link them to a source area of the Canadian Shield. In particular, statistical differences in types and weight percent of heavy minerals distinguished the lobes (Gwyn and Dreimanis, 1979; Dworkin et al., 1985). We note that these studies assumed the heavy minerals in the till were derived directly from igneous source rocks of the Canadian Shield and not from local Paleozoic clastic rocks. Gwyn and Dreimanis (1979) investigated differences between till samples along the southern margin of the Canadian Shield across the width of Ontario, with an emphasis on the 1300-950 Ma and >2500 Ma bedrock provinces. They found that till samples overlying $>2500$ Ma bedrock are $<1 \%$ heavy minerals and samples overlying 1300-950 Ma bedrock are $>1 \%$ heavy minerals and that key differences existed between abundances of the magnetic fraction, tremolite, clinopyroxene, purple and red garnets, epidote, and opaque minerals in tills along the Shield edge. Dworkin et al. (1985) studied till in southern Michigan and determined that tills from the three lobes (Lake Michigan, Huron-Erie, and Saginaw Lobes) could be differentiated based on heavy mineral composition. They used the results of Gwyn and Dreimanis (1979) to reconstruct flow paths for the lobes, tracing heavy mineral characteristics back to a Canadian Shield source. 
The results of our zircon study suggest that the assumption that heavy minerals are exclusively derived directly from Canadian Shield is problematic. Because zircon is also considered a heavy mineral, we assume it would have a similar transport history as the other heavy minerals in the till. For example, If LML till contains only heavy minerals that indicate a $>2500$ Ma source, then the zircons should also reflect this age. However, a lower proportion zircon ages are $>2500 \mathrm{Ma}$ compared to $1300-950$ Ma grains in the LML till. The same is true for the SL sample. Based on the flow lines of Margold et al. (2015b) and Shaw et al. (2010), ice depositing this till flowed primary over $>2500$ Ma rocks, yet the detrital zircon signature is dominated by $1300-950 \mathrm{Ma}$ grains. The mixture of detrital zircon ages does not support the same assumption made in previous heavy mineral analysis that the till was derived directly from a Shield source. Further work must be completed to understand why the heavy minerals and detrital zircon analyses yield different conclusions of till provenance.

Unless there are unique heavy minerals limited to a specific geographic region, it is challenging to trace them back to a specific bedrock source with certainty, based solely on mineral type and abundance. The advantage to using detrital zircon $\mathrm{U}-\mathrm{Pb}$ geochronology is that it provides both a mineralogical signal and a crystallization age that can be directly linked back to the primary igneous source. This is most straightforward when igneous rocks are the only source of zircons. Recycling of grains from igneous bedrock to younger sedimentary rocks to glacial till can increase the complexity of tracing the grains back to the original erosional source. However our results quite clearly indicate that grains from local Paleozoic bedrock are a larger contributor to the till than igneous sources of the Canadian Shield.

\section{Conclusions}


We conclude from this pilot study that detrital zircon $\mathrm{U}-\mathrm{Pb}$ geochronology does not yield obviously different, unique age signatures for the till samples from three ice lobes in northern Indiana. Overall, all the samples are dominated by 1600-950 Ma grains with a much smaller $>2500$ Ma component. The age distributions in the tills are similar to age distributions in the underlying Paleozoic bedrock and lead us to the conclusion that it is more likely that the till is primarily being derived from more local Paleozoic bedrock than from igneous rocks further upstream. Although erratics from the Canadian Shield occur in the tills (Coram, 2011), our data indicate igneous rocks of the Canadian Shield cannot be the dominant contributor of sediment, at least to the sand size fraction of the tills in Indiana. In order to more fully understand the provenance signals and reconstruct the southern margin of the Laurentide Ice Sheet, data from a variety of provenance methods has to be reconciled keeping in mind the inherent biases in each method. Our conclusions also have implications for understanding transport distances of glacial debris and the recycling of older tills into younger deposits.

A larger data set of tills must be collected to fully test the conclusions reached with this pilot study. Although the detrital zircon age populations of the samples overlap and statistical tests show some similarity, the distribution (bimodal, unimodal, even) of ages is not identical between the samples. Additional analyses could be used to evaluate whether these patterns are robust and, therefore, useful. In addition, the current sample set represents a single point of each glacial lobe and may not be representative of the glacial lobe as a whole. Increasing the sample set stratigraphically and spatially across each lobe will provide key information on whether detrital zircon ages in till are consistent through time and space for a particular lobe and whether sediment is recycled between successive glacial advances.

\section{Acknowledgments}


Funding for this project was provided by the Indiana University-Purdue University Indianapolis Undergraduate Research Opportunity Program Grant to S. Brickles and by the Indiana Geological Survey. We would like to thank Jeff Vervoort at the Washington State University Geoanalytical Laboratory and Victor Valencia at the University of Idaho for assistance with sample preparation and data production. Discussions with Henry Loope and Todd Thompson were extremely helpful as were comments from two anonymous reviewers.

\section{References Cited}

Alley, R.B., Cuffey, K.M., Evenson, E.B., Strasser, J.C., Lawson, D.E., Larson, G.J., 1997. How glaciers entrain and transport basal sediment: physical constraints. Quaternary Science Reviews 16, 1017-1038.

Anderson, R., 1957. Pebble and sand lithology of the major Wisconsin glacial lobes of the central lowland. Geological Society of America Bulletin 68, 1415-1460.

Bleuer, N., 1975. The Stone Creek Section: a historical key to the glacial stratigraphy of westcentral Indiana. Indiana Geological Survey Occasional Paper 11.

Boothroyd, J., 2012. Carboniferous provenance trends from clastic strata of the Michigan Basin. Thesis, Michigan State University.

Boulton, G.S., 1996. Theory of glacial erosion, transport and deposition as a consequence of subglacial sediment deformation. Journal of Glaciology 42(140), 43-62.

Clark, P.U., 1987. Subglacial sediment dispersal and till composition. The Journal of Geology 95(4), 527-541. 
Colgan, P.M., Mickelson, D.M., Cutler, P.M., 2003. Ice-marginal terrestrial landsystems:

southern-Laurentide Ice Sheet margin. In: Evans, D.J.A. (Ed), Glacial Landsystems. Routledge, New York, pp. 111-142.

Coram, M., 2011. Stratigraphy and provenance of Late Pleistocene glacial sediments in the Pontiac south quadrangle, southeastern Michigan. Thesis, Wayne State University.

Curry, B.B., Grimley, D.A., McKay, E.D., 2011. Quaternary glaciations in Illinois. In Ehlers, J., Gibbard, P.L., Hughes, P.D. (Eds.), Quaternary glaciations - extent and chronology: a closer look. Developments in Quaternary Sciences 15, 467-487.

Dickinson, W.R., 2008. Impact of differential zircon fertility of granitoid basement rocks in North America on age populations of detrital zircons and implications for granite petrogenesis. Earth and Planetary Science Letters 275, 80-92.

Dickinson, W.R., Gehrels, G.E., Marzoil, J.E., 2010. Detrital zircons from fluvial Jurassic strata of the Michigan basin: Implications for the transcontinental Jurassic paleoriver hypothesis. Geology 38, 499-502.

Dworkin, S.I., Larson, G.J., Monaghan, G.W., 1985. Late Wisconsinan ice flow reconstruction for the central Great Lakes region. Canadian Journal of Earth Sciences 22, 935-940.

Dyke, A.S., Andrews, J.T., Clark, P.U., England, J.H., Miller, G.J., Shaw, J., Veillette, J.J., 2002. The Laurentide and Innuitian Ice Sheets during the Last Glacial Maximum. Quaternary Science Reviews 21, 9-31.

Esch, J., 2011. Michigan bedrock topography, glacial drift thickness and bedrock outcrop maps. Geological Society of America Abstracts with Programs 43(1), 56.

Farrand, W.R., Mickelson, D.M., Cowan, W.R., Goebel, J.E., Richmond, G.M., Fullerton, D.S., 1983. Quaternary geologic map of the Lake Superior $4^{\circ} \times 6^{\circ}$ quadrangle, United States and 
Canada. Quaternary Geologic Atlas of the United States Map I-1420 (NL-16). U.S. Geological Survey.

Fraser, G.S., 1993. Sedimentology and history of Late Wisconsin alluviation of the Wabash Valley. Indiana Geological Survey Special Report 56.

Fullerton, D.S., Cowan, W.R., Sevon, W.D., Goldthwait, R.P., Farrand, W.R., Muller, E.H., Behling, R.E., Stravers, J.A., Richmond, G.M., 1983. Quaternary geologic map of the Lake Erie $4^{\circ} \times 6^{\circ}$ quadrangle, United States. Quaternary Geologic Atlas of the United States Map I-1420 (NK-17). U.S. Geological Survey.

Fullerton, D.S., Sevon, W.D., Muller, E.H., Judson, S., Black, R.F., Wagner, P.W., Hartshorn, J.H., Chapman, W.F., Cowan, W.D., 1992. Quaternary geologic map of the Hudson River $4^{\circ} \times 6^{\circ}$ quadrangle, United States. Quaternary Geologic Atlas of the United States Map I-1420 (NK-18). U.S. Geological Survey.

Gadd, N.R., Veillette, J.J., Fullerton, D.S., Wagner, P.W., Chapman, W.R., 1993. Quaternary geologic map of the Ottawa $4^{\circ} \times 6^{\circ}$ quadrangle, United States. Quaternary Geologic Atlas of the United States Map I-1420 (NL-18). U.S. Geological Survey.

Garrity, C.P., Soller, D.R., 2009. Database of the geologic map of North America. U.S. Geological Survey Data Series 424.

Gaschnig, R.M., Vervoort, J.D., Lewis, R.S., Tikoff, B., 2013. Probing for Proterozoic and Archean crust in the northern U.S. Cordillera with inherited zircon from the Idaho batholith. GSA Bulletin 125(1/2), 73-88.

Gehrels, G.E., 2000. Introduction to detrital zircon studies of Paleozoic and Triassic strata in western Nevada and northern California. In Soreghan, M.J. and Gehrels, G.E. (Eds), Paleozoic 
and Triassic paleogeography and tectonics of western Nevada and northern California. GSA Special Papers 347, pp. 1-17.

Glover, K.C., Lowell, T.V., Wiles, G.C., Pair, D., Applegate, P. Hajdas, I., 2011. Deglaciation, basin formation and post-glacial climate change from a regional network of sediment core sites in Ohio and eastern Indiana. Quaternary Research 76, 401-410.

Gooding, A.M., 1973. Characteristics of late Wisconsinan tills in eastern Indiana. Indiana Geological Survey Bulletin 49.

Gooding A.M., 1975. The Sidney interstadial and the Late Wisconsin history in Indiana and Ohio. American Journal of Science 275, 993-1011.

Gray, H.H., Bleuer, N.K., Lineback, J.A., Swadley, W.C., Richmond, G.M., Miller, R.A., Goldthwait, R.P., Ward, R.A., 1991. Quaternary geologic map of the Louisville $4^{\circ} \times 6^{\circ}$ quadrangle, United States. Quaternary Geologic Atlas of the United States Map I-1420 (NJ-16). U.S. Geological Survey.

Guynn, J., Gehrels, G., 2010. Comparison of detrital zircon age distributions using the K-S test. University of Arizona Laserchron Center.

Gwyn, G.H.J., and Dreimanis, A., 1979. Heavy mineral assemblages in tills and their use in distinguishing glacial lobes in the Great Lakes region. Canadian Journal of Earth Sciences 16(12), 2219-2235.

Hall, R.D., Anderson, A.K., 2000. Compariative soil development of Quaternary paleosols of the central United States. Palaeogeography, Palaeoclimatology, Palaeoecology 158, 109-145.

Hall, R.D., Anderson, A.K., 2001. Quaternary record at Cagles Mill, Putnam County, Indiana. Proceedings of the Indiana Academy of Science 110, 9-22. 
Harrison, W., 1960. Original bedrock composition of Wisconsin till in central Indiana. Journal of Sedimentary Petrology 30(3), 432-446.

Hooke, R.L., Cummings, D.I., Lesemann, J.E., Sharpe, D.R., 2013. Genesis of dispersal plumes in till. Canadian Journal of Earth Sciences 50(8), 432-446.

Karls, D.A., 2005. Petrographic and geochemical analysis of detrital magnetite in late Wisconsinan tills in eastern Indiana and western Ohio. Thesis, Ball State University.

Larson, P.C., Mooers, H.D., 2004. Glacial indicator dispersal processes: a conceptual model. Boreas 33, 238-249.

Larson, P., Mooers, H., 2005. Generation of a heavy-mineral glacial indicator dispersal train from a diabase sill, Nipigon region, northwestern Ontario. Canadian Journal of Earth Sciences 42, 1601-1613.

Leverett, F., Taylor, F.B., 1915. The Pleistocene of Indiana and Michigan and the history of the Great Lakes. Monographs of the U.S. Geological Survey 53.

Licht, K.J., Hemming, S.R., 2017. Analysis of Antarctic glacigenic sediment provenance through geochemical and petrologic applications. Quaternary Science Reviews 164, 1-24.

Licht, K., Palmer, E.F., 2013. Erosion and transport by Byrd Glacier, Antarctica during the Last Glacial Maximum. Quaternary Science Reviews 62, 32-48.

Licht, K., Hennessy, A.J., Welke, B.M., 2014. The U-Pb detrital zircon signature of West Antarctic ice stream tills in the Ross embayment, with implications for Last Glacial Maximum ice flow reconstructions. Antarctic Science 26(6), 687-697.

Lineback, J.A., Bleuer, N.K., Mickelson, D.M., Farrand, W.R., Goldthwait, R.P., 1983.

Quaternary geologic map of the Chicago $4^{\circ} \times 6^{\circ}$ quadrangle, United States. Quaternary Geologic Atlas of the United States Map I-1420 (NK-16). U.S. Geological Survey. 
Malott, C.A., 1922. The physiography of Indiana. In: Handbook of Indiana Geology. Indiana Department of Conservation 32, pp. 59-256.

Margold, M., Stokes, C.R., Clark, C.D., 2015a. Ice streams in the Laurentide Ice Sheet: identification, characteristics, and comparison to modern ice sheets. Earth Science Reviews $143,117-146$.

Margold, M., Stokes, C.R., Clark, C.D., Kleman, J., 2015b. Ice streams in the Laurentide Ice Sheet: a new mapping inventory. Journal of Maps 11(3), 380-395.

Mickelson, D.M., Colgan, P.M., 2003. The southern Laurentide Ice Sheet. In: Gillespie, A.R., Porter, S.C., Atwater, B.F. (Eds), The Quaternary Period in the United States. Elsevier, New York, pp. 1-17.

Mickelson, D.M., Clayton, L., Fullerton, D.S., Borns Jr, H.W., 1983. The Late Wisconsin glacial record of the Laurentide Ice Sheet in the United States. In: Wright Jr., H.E., Porter, S.C. (Eds), Late Quaternary environments of the United States I: the Late Pleistocene. University of Minnesota Press, Minneapolis, pp. 3-30.

Moecher, D.P., Samson, S.D., 2006. Differential zircon fertility of source terranes and natural bias in the detrital zircon record: implications of sedimentary provenance analysis. Earth and Planetary Science Letters 247, 252-266.

Palmer, E.F., Licht, K., Swope, R.J., Hemming, S.R., 2012. Nunatak moraines as a repository of what lies beneath the East Antarctic ice sheet. Geological Society of America Special Paper 487, 97-104.

Potter, P.E., Pryor, W.A., 1961. Dispersal centers of Paleozoic and later clastics of the upper Mississippi Valley and adjacent areas. Geological Society of America Bulletin 72, 1195-1250. 
Potter, P.E., Siever, R., 1956. Sources of basal Pennsylvanian sediments in the eastern interior basin, 1. Cross bedding. The Journal of Geology 64(3), 225-244.

Prest, V.K., Donaldson, J.A., Mooers, H.D., 2000. The omar story: the role of omars in assessing glacial history of west-central North America. Géographie physique et Quaternaire 54(3), 257-270.

Richmond, G.M., Fullerton, D.S., Christiansen, A.C., Howard, A.D., Behling, R.E., Wheeler, W.H., Daniels, R.B., Swadley, W.C., Goldthwait, R.P., Sevon, W.D., Miller, R.A., 1991. Quaternary geologic map of the Blue Ridge $4^{\circ} \times 6^{\circ}$ quadrangle, United States. Quaternary Geologic Atlas of the United States Map I-1420 (NJ-17). U.S. Geological Survey.

Sado, E.V., Fullerton, D.S., Baker, C.L., Farrand, W.R., 1993. Quaternary geologic map of the Sudbury $4^{\circ} \times 6^{\circ}$ quadrangle, United States. Quaternary Geologic Atlas of the United States Map I-1420 (NL-17). U.S. Geological Survey.

Sado, E.V., Fullerton, D.S., Farrand, W.R., 1994. Quaternary geologic map of the Lake Nipigon $4^{\circ} \times 6^{\circ}$ quadrangle, United States. Quaternary Geologic Atlas of the United States Map I-1420 (NM-16). U.S. Geological Survey.

Satkoski, A.M., Wilkinson, B.H., Hietpas, J., Samson, S.D., 2013. Likeness among detrital zircon populations - an approach to the comparison of age frequency data in time and space. GSA Bulletin 125(11/12), 1783-1799.

Siever, R., Potter, P.E., 1956. Sources of basal Pennsylvanian sediments in the eastern interior basin, 2. Sedimentary petrology. The Journal of Geology 64(4), 317-335.

Shaw, J., Sharpe, D.R., Harris, J., Lemkow, D., Pehleman, D., 2010. Digital landform patterns for glaciated regions of Canada - a predictive model of flowlines based on topographic and LANDSAT 7 data. Geological Survey of Canada. Open File Report 6190. 
Shideler, G.L., 1969. Dispersal patterns of Pennsylvania sandstones in the Michigan Basin. Journal of Sedimentary Petrology 39(3), 1229-1237.

Shilts, W., 1993. Geological Survey of Canada's contributions to understanding the composition of glacial sediments. Canadian Journal of Earth Sciences 30(2), 333-353.Syverson, K.M., Colgan, P.M., 2011. In Ehlers, J., Gibbard, P.L., Hughes, P.D. (Eds.), Quaternary glaciations extent and chronology: a closer look. Developments in Quaternary Sciences 15, 537-552.

Taylor, K.S., Faure, G., 1981. Rb-Sr dating of detrital feldspar: a new method to study till. The Journal of Geology 89(1), 97-107.

Wayne, W.J., 1956. Thickness of drift and bedrock physiography of Indiana north of the Wisconsin glacial boundary. Indiana Geological Survey Report of Progress 7.

Wayne W.J., 1965. The Crawfordsville and Knightstown moraines in Indiana. Indiana Geological Survey Report of Progress 28.

Wayne, W.J., 1967. The Erie Lobe margin in east central Indiana during the Wisconsin glaciation. Proceedings of the Indiana Academy of Science 77, 279-291.

Wayne, W.J., Thornbury, W.D., 1951. Glacial geology of Wabash County, Indiana. Indiana Geological Survey Bulletin 5.

Whitmeyer, S.J., Karlstrom, K.E., 2007. Tectonic model for the Proterozoic growth of North America. Geosphere 3, 220-259. 


\section{Tables}

Table 1. Sample information

Table 2. Percentage of grains within each age group raw and adjusted by zircon fertility factor

Table 3. All peak ages for each sample

Table 4. Results of statistical analyses used to compare the datasets

\section{Figures}

Figure 1. Sample locations, igneous sources, flow lines

Figure 2. Sample locations with underlying parent material from ISEE

Figure 3. Image showing rounded grains

Figure 4. Probability density plots

Figure 5. Possible sedimentary bedrock sources of Michigan Basin

\section{Supplementary Tables}

Table 1. Lake Michigan Lobe (LML) U-Pb geochronology data set and sample location

Table 2. Saginaw Lobe (SL) U-Pb geochronology data set and sample location

Table 3. Huron-Erie Lobe (HEL) U-Pb geochronology data set and sample location

Table 4. Fountain County (UN) U-Pb geochronology data set and sample location

Table 5. Percentage of grains from bedrock samples of other studies within each age group raw and adjusted by zircon fertility factor (ZFF)

Table 6. Results of statistical comparison between the bedrock samples and till samples. 


\section{Table 1.}

Sample information

\begin{tabular}{|c|c|c|c|c|c|c|c|}
\hline $\begin{array}{c}\text { Sample } \\
\text { name }\end{array}$ & Latitude* $^{*}$ & Longitude* $^{*}$ & County & Ice lobe & $\begin{array}{l}\text { Associated } \\
\text { moraine }\end{array}$ & Soil series & $\begin{array}{c}\text { Parent } \\
\text { material }\end{array}$ \\
\hline $\mathrm{HEL}^{1}$ & $40.735861^{\circ} \mathrm{N}$ & $85.708167^{\circ} \mathrm{W}$ & Wabash & Huron-Erie Lobe & Mississinewa & $\begin{array}{l}\text { Glynwood } \\
\text { series }\end{array}$ & $\begin{array}{l}\text { Clayey } \\
\text { Wisconsin } \\
\text { till }\end{array}$ \\
\hline $\mathrm{SL}^{2}$ & $41.462750^{\circ} \mathrm{N}$ & $86.038722^{\circ} \mathrm{W}$ & Elkhart & Saginaw Lobe & Packerton & $\begin{array}{l}\text { Brookston } \\
\text { loam }\end{array}$ & $\begin{array}{l}\text { Loamy } \\
\text { Wisconsin } \\
\text { till }\end{array}$ \\
\hline $\mathrm{LML}^{3}$ & $41.527694^{\circ} \mathrm{N}$ & $87.296611^{\circ} \mathrm{W}$ & Lake & $\begin{array}{l}\text { Lake Michigan } \\
\text { Lobe }\end{array}$ & Valparaiso & $\begin{array}{l}\text { Pewamo } \\
\text { series }\end{array}$ & $\begin{array}{l}\text { Clayey } \\
\text { Wisconsin } \\
\text { till }\end{array}$ \\
\hline $\mathrm{UN}^{4}$ & $40.046167^{\circ} \mathrm{N}$ & $87.118722^{\circ} \mathrm{W}$ & Fountain & $\begin{array}{l}\text { Lake Michigan } \\
\text { Lobe or Huron- } \\
\text { Erie Lobe }\end{array}$ & $\begin{array}{l}\text { Crawfordsvill } \\
\text { e, } \\
\text { Champaign }\end{array}$ & $\begin{array}{l}\text { Treaty silty } \\
\text { clay loam }\end{array}$ & $\begin{array}{l}\text { Loamy } \\
\text { Wisconsin } \\
\text { till }\end{array}$ \\
\hline
\end{tabular}

${ }^{1}$ Huron-Erie Lobe; ${ }^{2}$ Saginaw Lobe; ${ }^{3}$ Lake Michigan Lobe; 4 'unknown' from Fountain County; ${ }^{*}$ coordinate datum is WGS84 
Table 2.

Percentage of grains within each age group raw and adjusted by zircon fertility factor (ZFF)

\begin{tabular}{cccccccccc}
\hline & \multicolumn{3}{c}{ raw } & \multicolumn{1}{c}{ adjusted } \\
\hline Age (Ma) & HEL & SL & LML & UN & ZFF & HEL & SL & LML & UN \\
\hline$<\mathbf{9 5 0}$ & $0 \%$ & $3 \%$ & $0 \%$ & $\mathbf{2} \%$ & 1 & $0 \%$ & $7 \%$ & $0 \%$ & $4 \%$ \\
$\mathbf{9 5 0 - 1 3 0 0}$ & $54 \%$ & $50 \%$ & $47 \%$ & $41 \%$ & 3.5 & $35 \%$ & $31 \%$ & $28 \%$ & $22 \%$ \\
$\mathbf{1 3 0 0 - 1 6 0 0}$ & $30 \%$ & $25 \%$ & $30 \%$ & $30 \%$ & 2.5 & $27 \%$ & $21 \%$ & $25 \%$ & $22 \%$ \\
$\mathbf{1 6 0 0 - 1 7 0 0}$ & $3 \%$ & $2 \%$ & $1 \%$ & $9 \%$ & 1 & $7 \%$ & $3 \%$ & $2 \%$ & $17 \%$ \\
$\mathbf{1 7 0 0 - 1 8 0 0}$ & $1 \%$ & $0 \%$ & $1 \%$ & $2 \%$ & 1 & $2 \%$ & $0 \%$ & $2 \%$ & $4 \%$ \\
$\mathbf{1 8 0 0 - 1 9 0 0}$ & $0 \%$ & $1 \%$ & $4 \%$ & $4 \%$ & 1 & $0 \%$ & $3 \%$ & $7 \%$ & $7 \%$ \\
$\mathbf{1 9 0 0 - 2 5 0 0}$ & $1 \%$ & $3 \%$ & $0 \%$ & $1 \%$ & 1 & $2 \%$ & $5 \%$ & $0 \%$ & $2 \%$ \\
$>\mathbf{2 5 0 0}$ & $12 \%$ & $14 \%$ & $18 \%$ & $12 \%$ & 1 & $26 \%$ & $29 \%$ & $37 \%$ & $22 \%$ \\
\hline
\end{tabular}


Table 3.

Detrital zircon age peaks

\begin{tabular}{|c|c|}
\hline Sample/Formation & Peak age Ma (number of grains) ${ }^{*}$ \\
\hline Huron-Erie till (HEL) & 1080(14), 1160(26), 1230(9), 1370(10), 1445(14), 1665(3), 2680(6) \\
\hline Saginaw till (SL) & $\begin{array}{l}\text { 1030(9), 1095(27), 1220(5), 1255(6), 1355(9), 1385(8), 1445(6), 1485(5), 1600(3), } \\
\text { 2675(6), 2695(6), 2725(4) }\end{array}$ \\
\hline Lake MI till (LML) & $\begin{array}{l}\text { 1015(5), 1105(17), 1205(13), 1235(14), 1355(11), 1450(17), 1590(3), 1850(4), } \\
\text { 2645(4), 2710(7) }\end{array}$ \\
\hline Unknown till (UN) & $\begin{array}{l}\text { 1010(8), 1055(10), 1110(11), 1170(12), 1275(3), 1340(4), 1450(14), 1580(4), 1655(6), } \\
\text { 1860(3), 2690(5), 2710(6) }\end{array}$ \\
\hline Ionia Formation ${ }^{1}$ & $\begin{array}{l}380(5), 410(5), 480(4), 940(9), 1045(23), 1095(23), 1145(20), 1180(16), 1280(5), \\
1325(4), 1390(4), 1455(5), 1500(9), 1650(11), 1665(10), 1690(6), 1740(5), 1765(6) \\
1810(3)\end{array}$ \\
\hline Eaton Sandstone ${ }^{2}$ & $\begin{array}{l}475(5), 1055(19), 1135(18), 1210(9), 1345(4), 1455(6), 1490(8), 1560(3), 1650(10) \\
1735(3), 1805(4), 1830(4), 2810(3), 2835(3)\end{array}$ \\
\hline Saginaw Formation ${ }^{2}$ & $\begin{array}{l}440(6), 460(6), 1035(22), 1150(18), 1170(18), 1270(8), 1340(7), 1365(8), 1465(6) \text {, } \\
1785(3)\end{array}$ \\
\hline Parma Sandstone $^{2}$ & $\begin{array}{l}435(4), 455(3), 1015(34), 1050(40), 1125(32), 1415(8), 1440(8), 1460(7), 1510(7), \\
1610(6), 1650(8), 1755(3), 1785(3), 1805(5), 1840(4), 1875(4)\end{array}$ \\
\hline Marshall Sandstone ${ }^{2}$ & $\begin{array}{l}\text { 115(3), 380(4), 400(6), 465(19), 1015(86), 1155(47), 1195(39), 1330(17), 1370(11), } \\
\text { 1465(12), 1490(15), 1515(13), 1585(4) }\end{array}$ \\
\hline
\end{tabular}

${ }^{1}$ Data from Dickinson et al. (2010); ' $D$ ata from Boothroyd (2012).

${ }^{*}$ Peak ages calculated using AgePick Excel macro provided by the University of Arizona

Laserchron Center. 
Table 4.

Results of statistical comparisons between samples

K-S Test

\begin{tabular}{llll}
\hline & HEL & SL & LML \\
\hline SL & 0.388 & & \\
LML & 0.496 & 0.106 & \\
UN & 0.046 & 0.032 & 0.509 \\
\hline
\end{tabular}

Degree of Likeness

\begin{tabular}{llll}
\hline & HEL & SL & LML \\
\hline SL & $73.0 \%$ & & \\
LML & $75.9 \%$ & $71.1 \%$ & \\
UN & $69.2 \%$ & $65.0 \%$ & $67.2 \%$ \\
\hline
\end{tabular}

Degree of Overlap

\begin{tabular}{llll}
\hline & HEL & SL & LML \\
\hline SL & 0.725 & & \\
LML & 0.784 & 0.788 & \\
UN & 0.793 & 0.737 & 0.805 \\
\hline
\end{tabular}

Degree of Similarity

\begin{tabular}{llll}
\hline & HEL & SL & LML \\
\hline SL & 0.855 & & \\
LML & 0.866 & 0.850 & \\
UN & 0.838 & 0.811 & 0.806 \\
\hline
\end{tabular}


Figure 1.

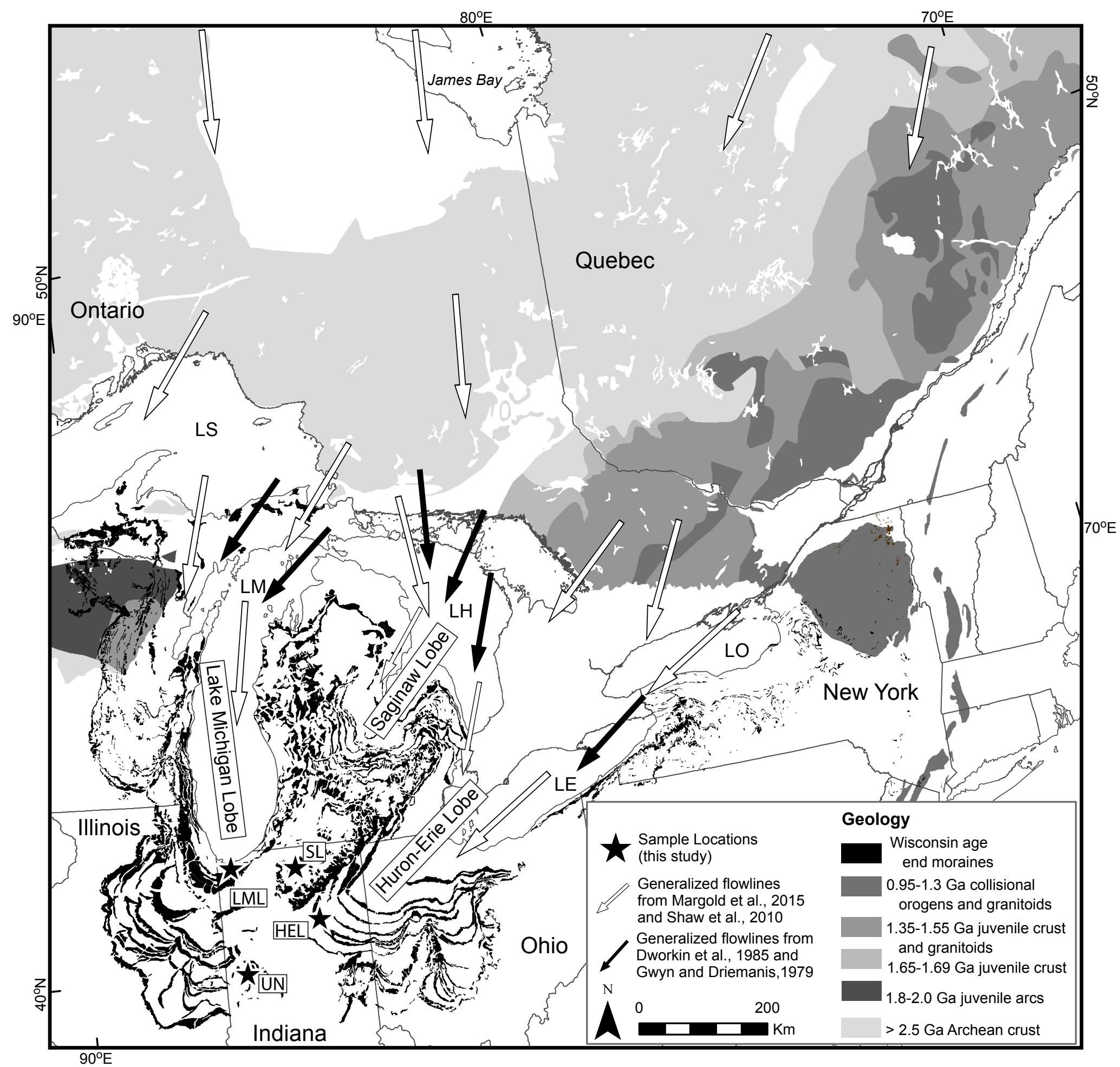


Figure 1.

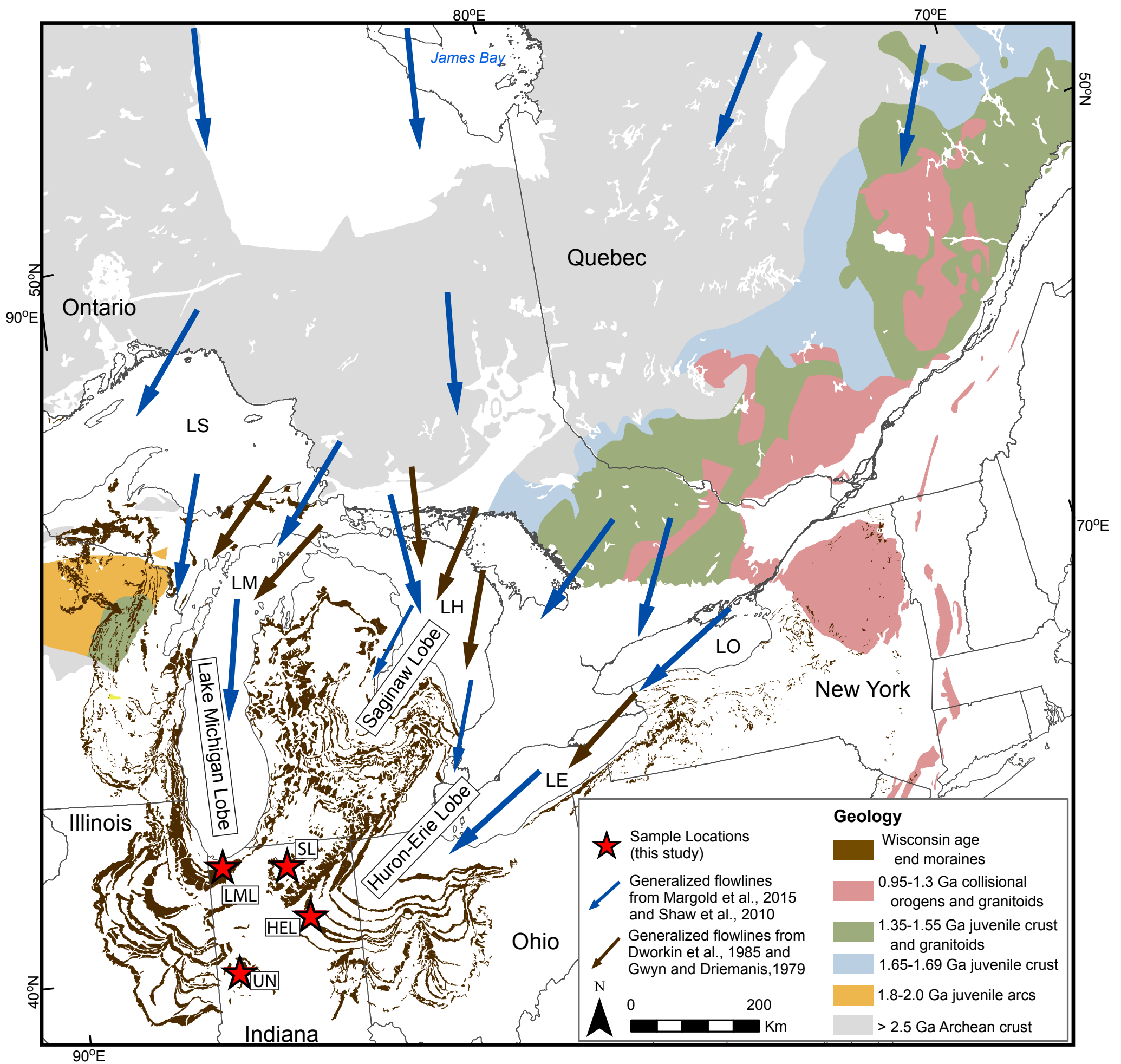


Figure 2.

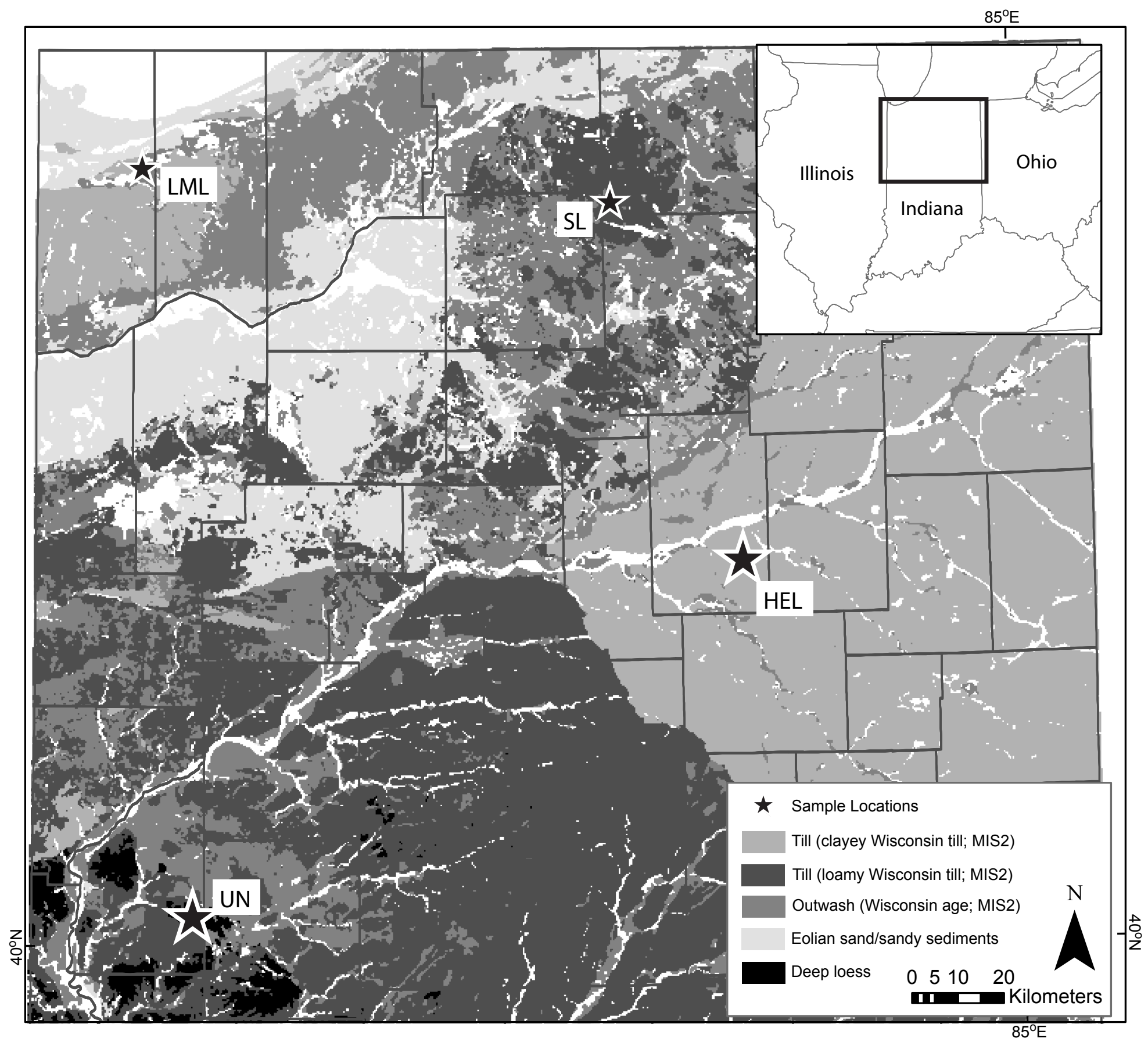


Figure 2.

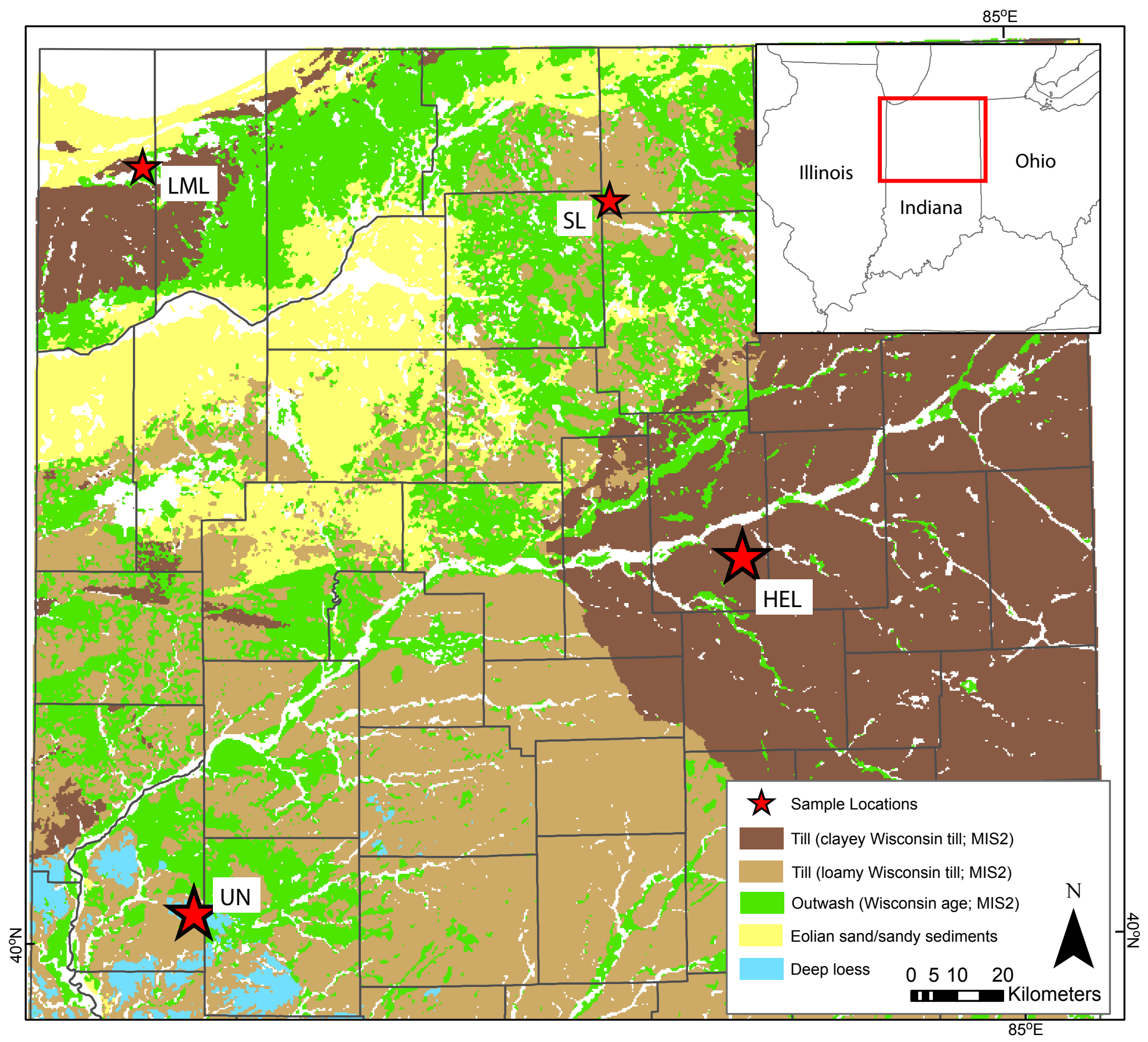


Figure 3.

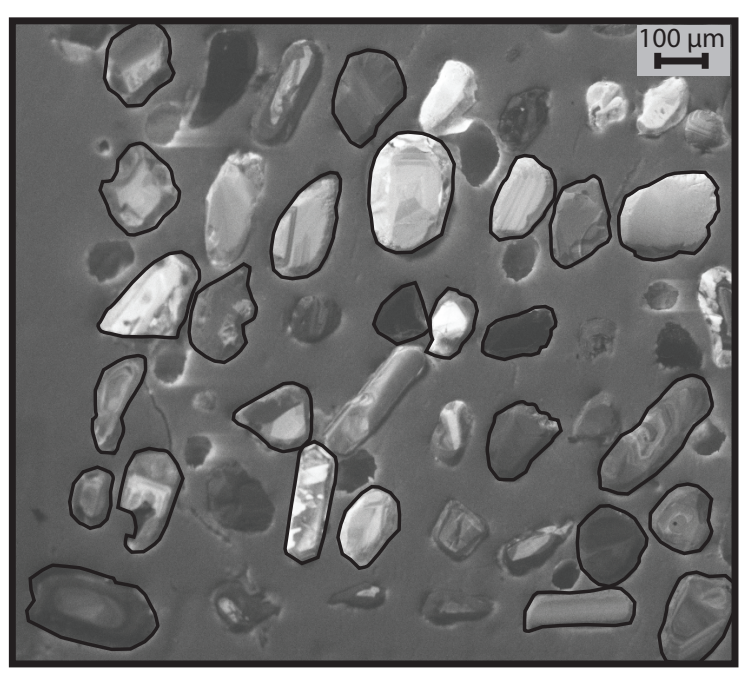


Figure 4 .

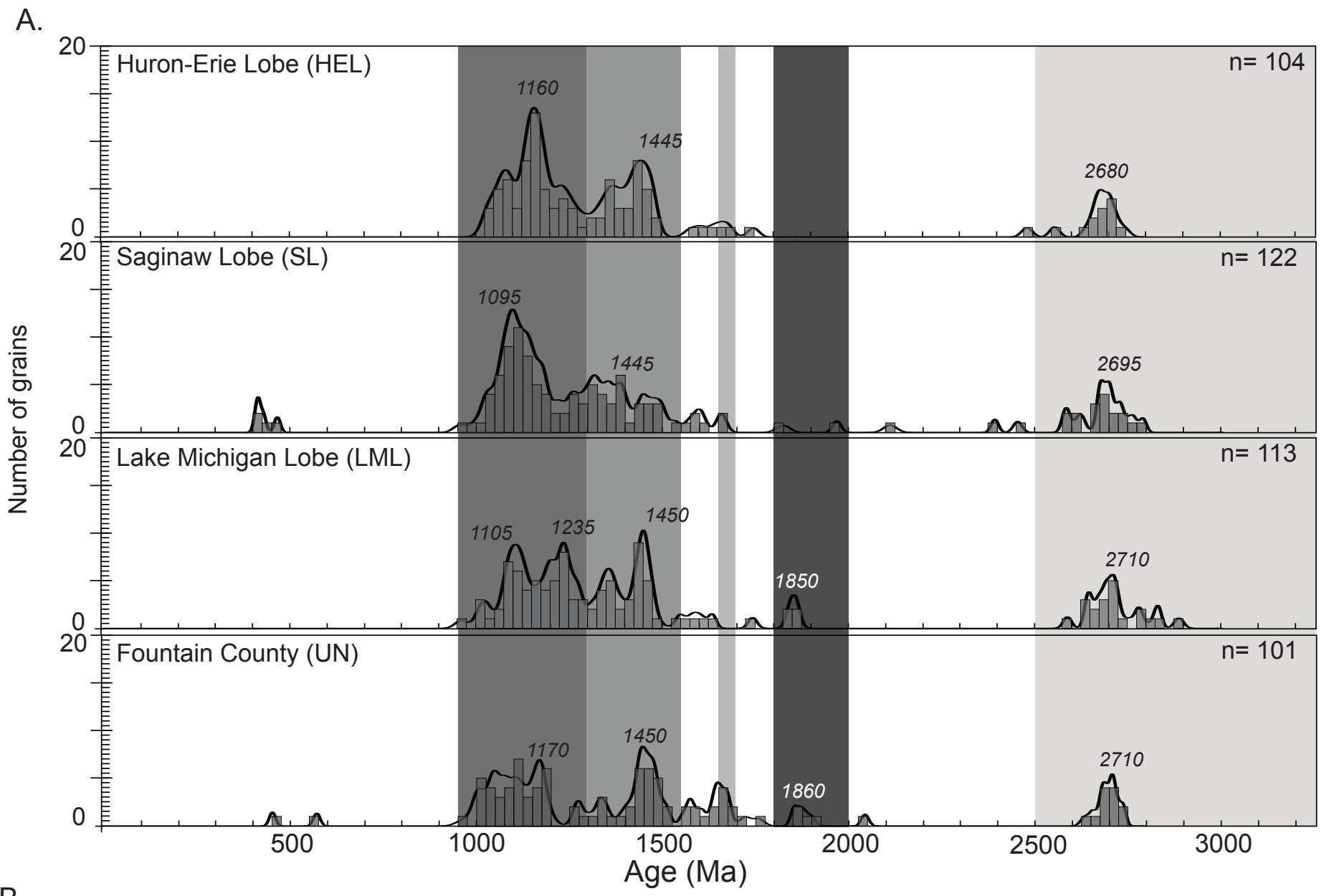

B.

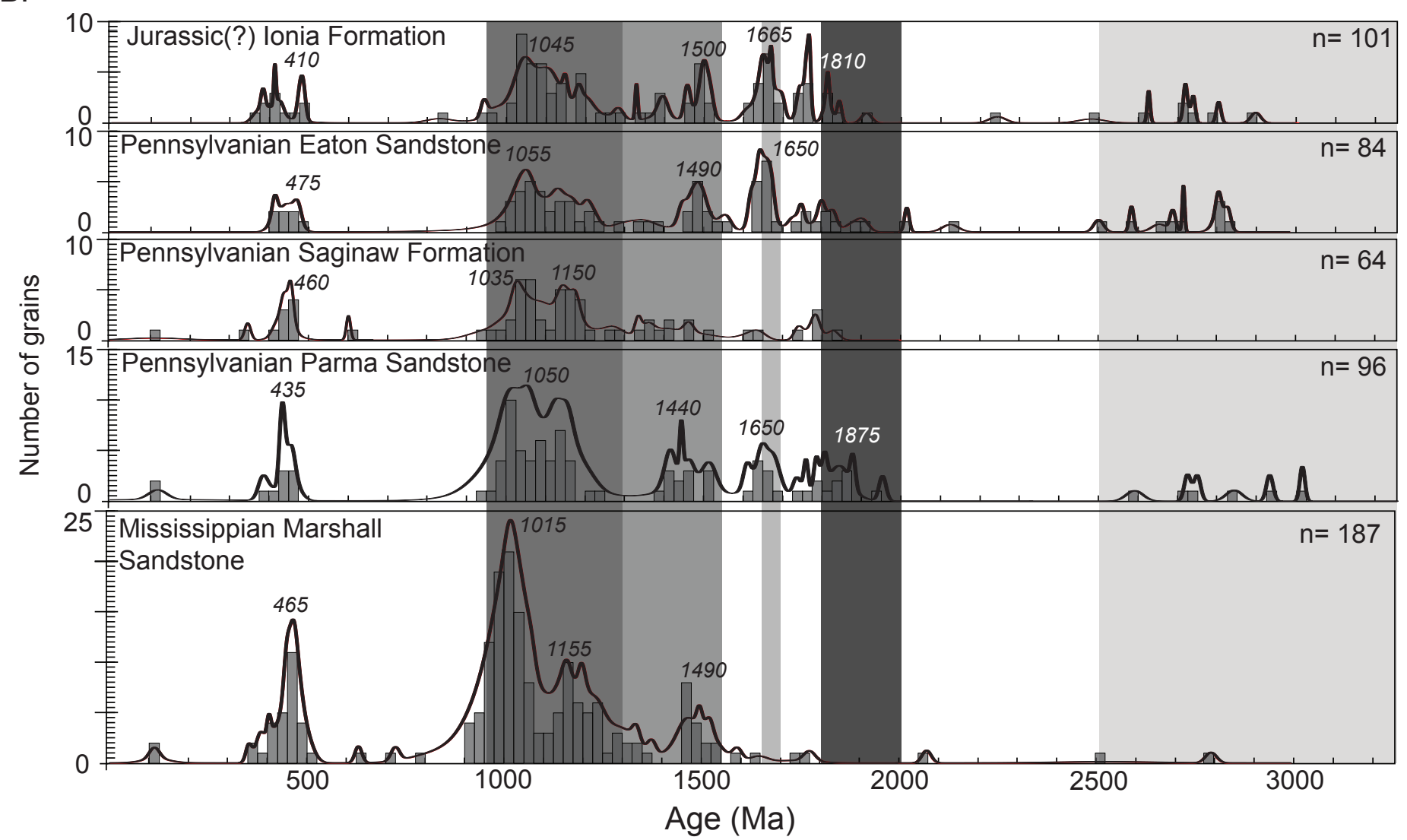


Figure 4.

A.

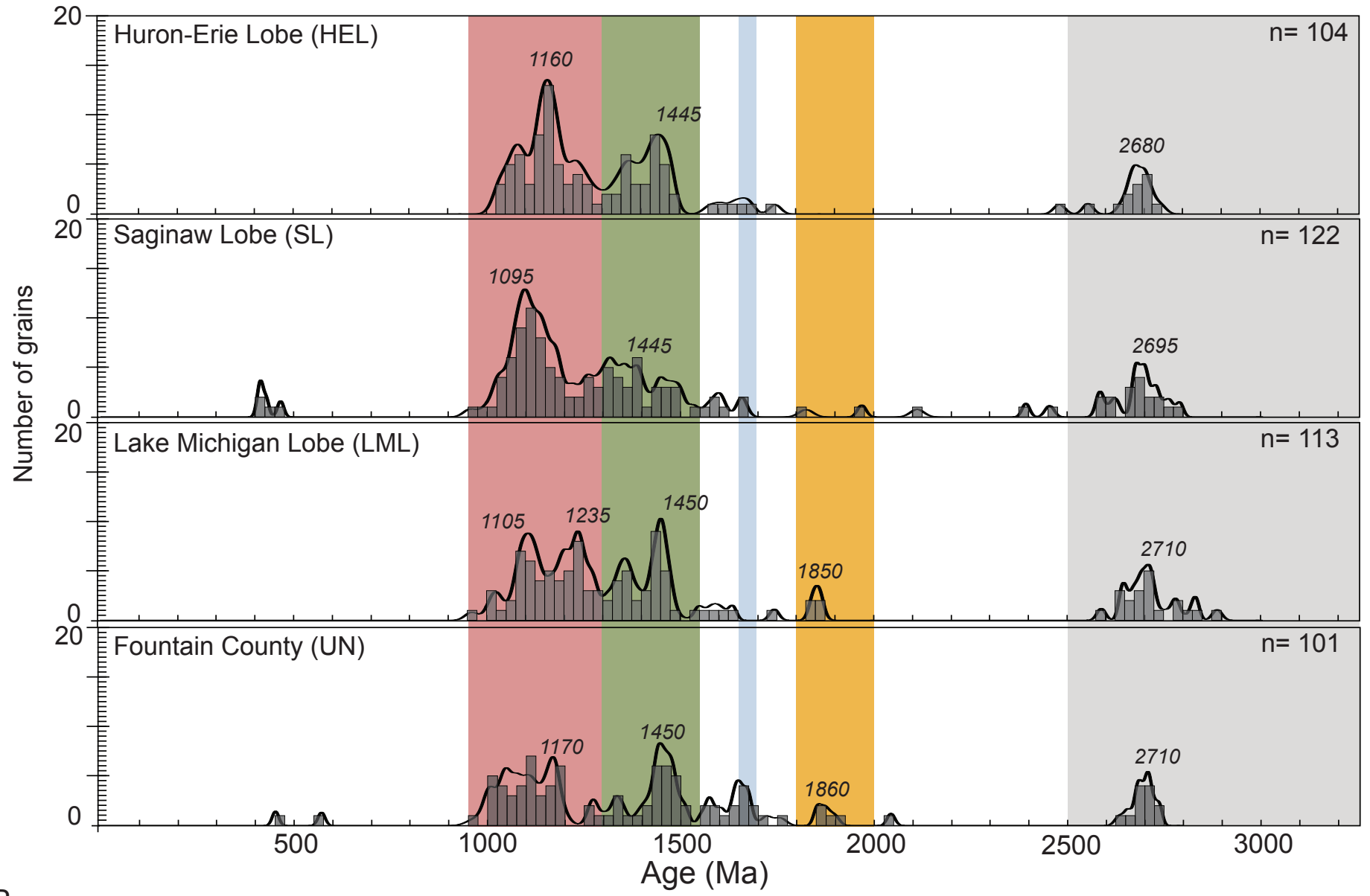

B.
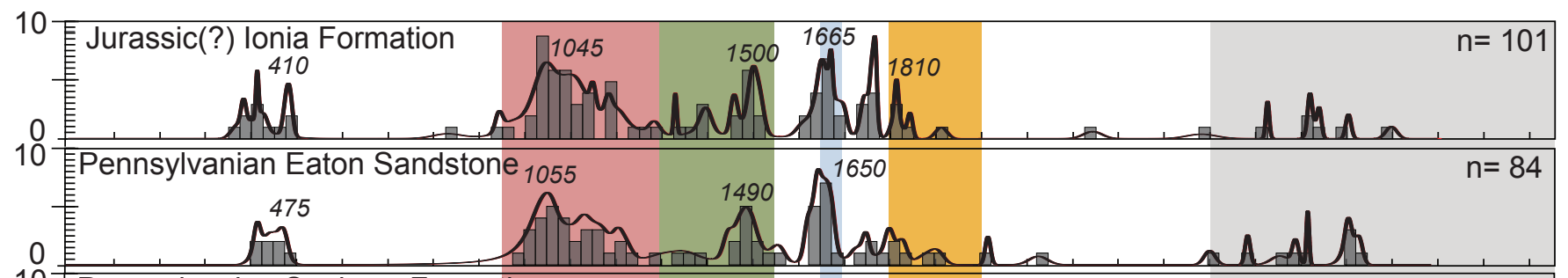

10 Pennsylvanian Saginaw Formation
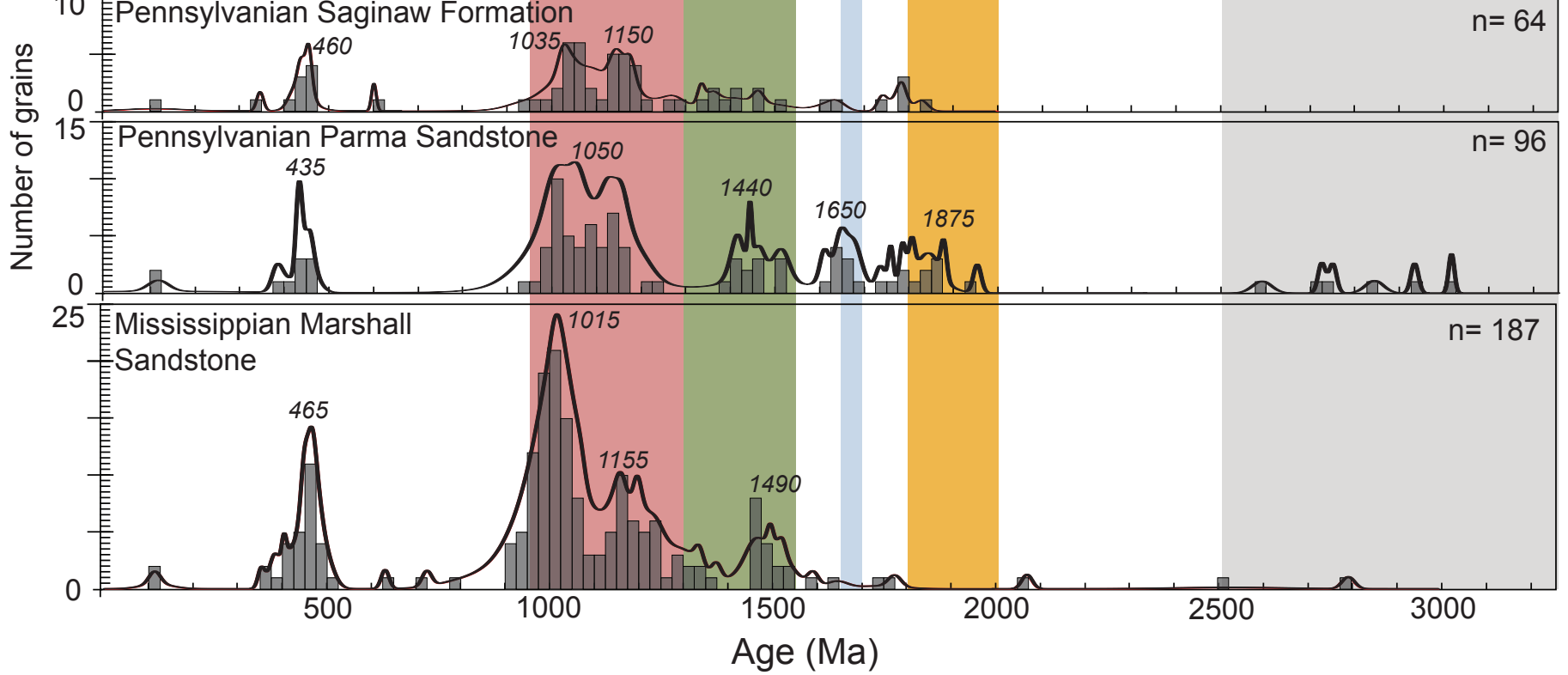
Figure 5.

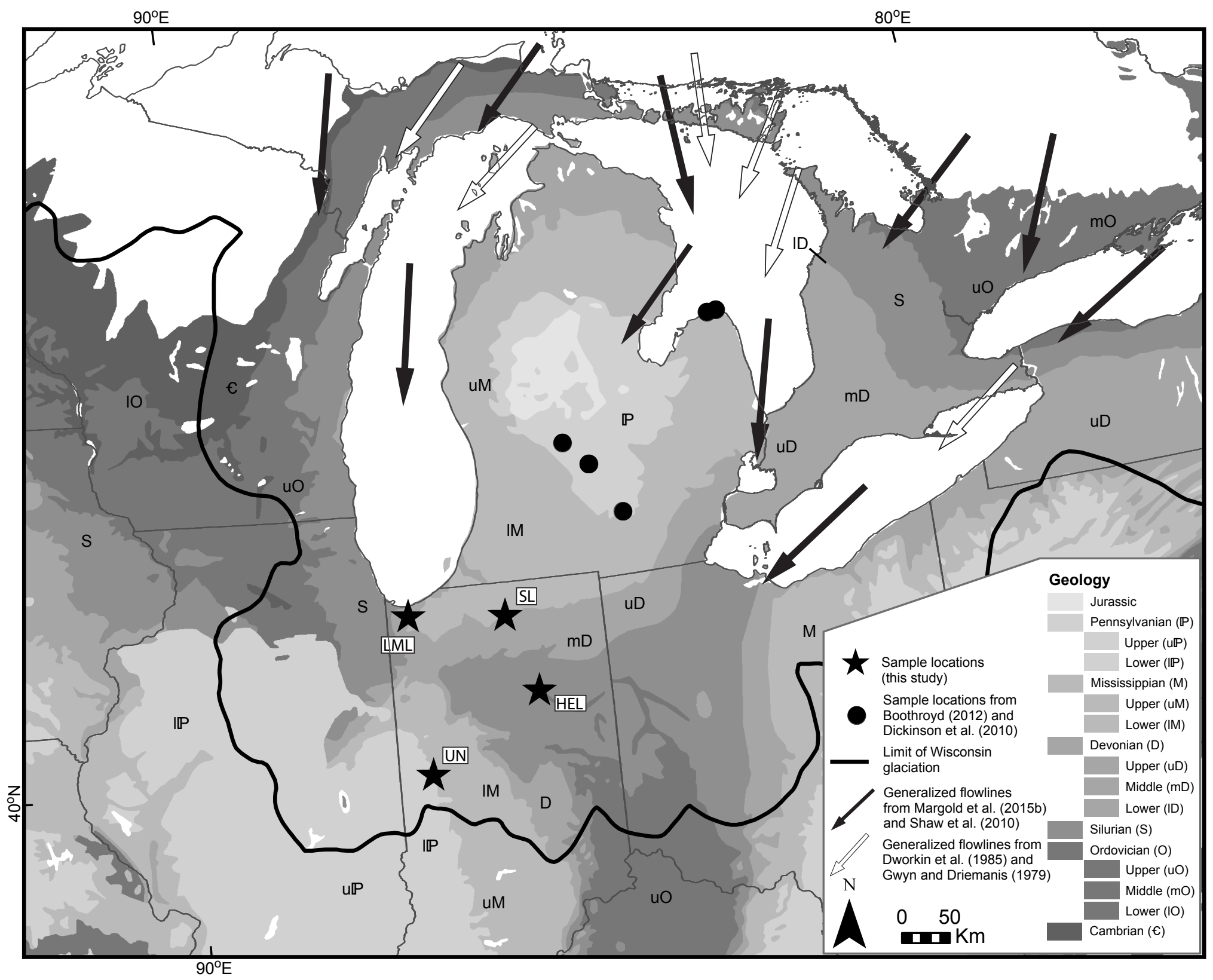


Figure 5.

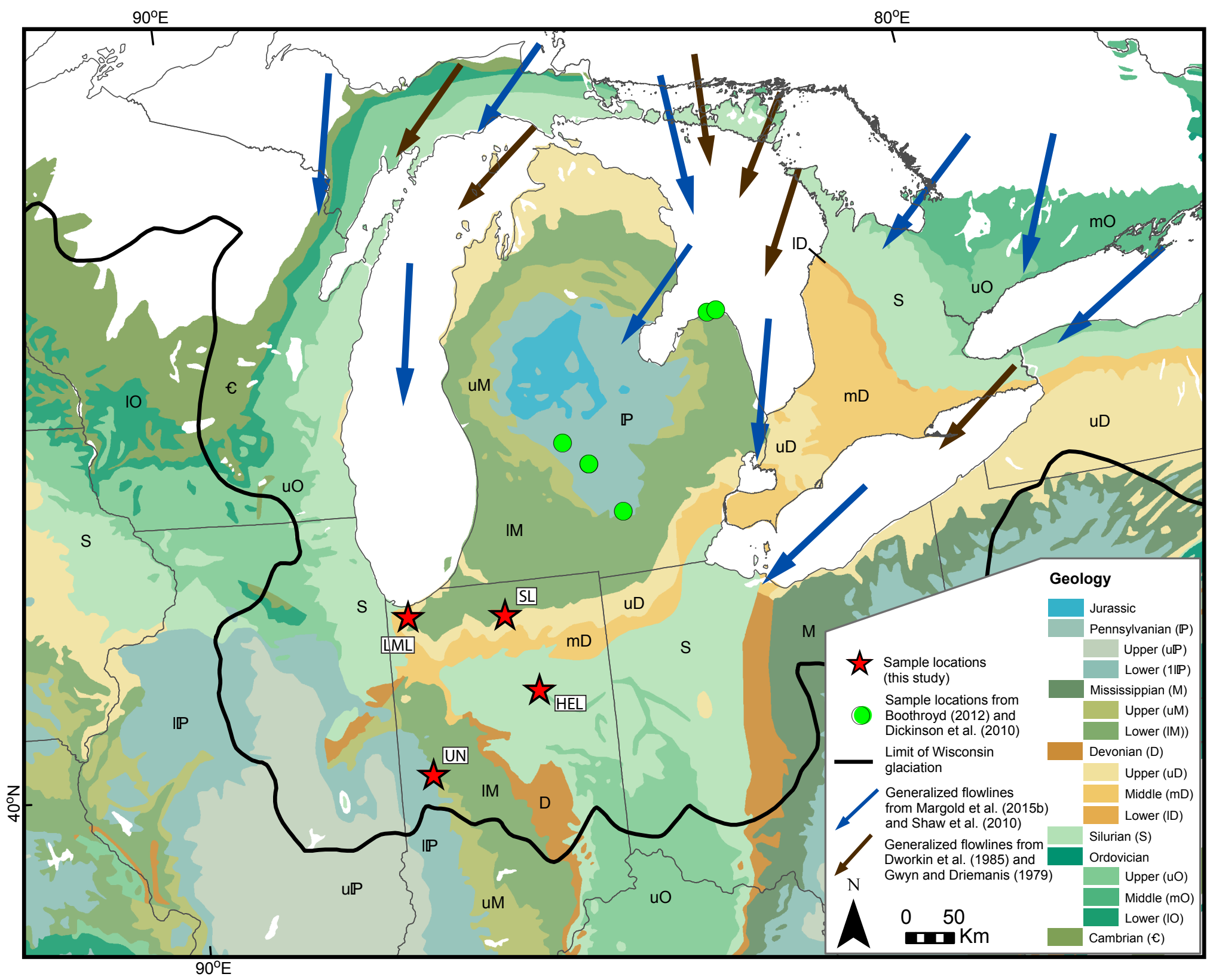


Supplementary Table 4. Summary of Washington State MC-ICPMS U-Pb zircon results for the Fountain County till sample Sample Location: 40.046166, -87.118722

\begin{tabular}{|c|c|c|c|c|c|c|c|c|c|}
\hline \multirow[b]{2}{*}{ Sample } & \multirow[b]{2}{*}{$\mathrm{Th} / \mathrm{U}$} & \multicolumn{4}{|c|}{ Intercept } & \multicolumn{4}{|c|}{ Apparent ages (Ma) } \\
\hline & & $\begin{array}{l}207 \mathrm{~Pb} \\
206 \mathrm{~Pb}\end{array}$ & $\begin{array}{l} \pm \\
\%\end{array}$ & $\begin{array}{c}238 \mathrm{U} \\
206 \mathrm{~Pb}\end{array}$ & $\begin{array}{l} \pm \\
\%\end{array}$ & $\begin{array}{c}206 \mathrm{~Pb} \\
238 \mathrm{U}\end{array}$ & $\begin{array}{c} \pm \\
(\mathrm{Ma})\end{array}$ & $\begin{array}{l}207 \mathrm{~Pb} \\
206 \mathrm{~Pb}\end{array}$ & $\begin{array}{c} \pm \\
\text { (Ma) }\end{array}$ \\
\hline FTC 1a 001a & 0.27 & 0.08 & 0.60 & 5.48 & 1.52 & 1080 & 15 & 1079 & 12 \\
\hline FTC_1a_002 & 0.25 & 0.08 & 0.66 & 4.96 & 1.55 & 1185 & 17 & 1162 & 13 \\
\hline FTC_1a_003 & 0.23 & 0.10 & 0.57 & 4.02 & 1.55 & 1433 & 20 & 1557 & 11 \\
\hline FTC_1a_004 & 0.33 & 0.09 & 0.79 & 4.09 & 1.60 & 1411 & 20 & 1478 & 15 \\
\hline FTC_1a_005 & 0.27 & 0.08 & 0.54 & 4.98 & 1.48 & 1179 & 16 & 1183 & 11 \\
\hline FTC1A_006 & 0.23 & 0.09 & 0.54 & 4.50 & 1.65 & 1293 & 19 & 1333 & 10 \\
\hline FTC1A_007 & 0.21 & 0.10 & 0.54 & 3.28 & 1.64 & 1715 & 25 & 1676 & 10 \\
\hline FTC1A_008 & 0.20 & 0.18 & 0.54 & 1.95 & 1.66 & 2670 & 36 & 2680 & 9 \\
\hline FTC1A_010 & 0.33 & 0.19 & 0.56 & 1.87 & 1.78 & 2764 & 40 & 2715 & 9 \\
\hline FTC1A_012 & 0.27 & 0.09 & 0.55 & 4.06 & 1.59 & 1420 & 20 & 1481 & 10 \\
\hline FTC1a_012b & 0.27 & 0.09 & 0.63 & 3.84 & 0.94 & 1493 & 12 & 1503 & 12 \\
\hline FTC1A_014 & 0.23 & 0.11 & 0.65 & 3.00 & 1.61 & 1853 & 26 & 1868 & 12 \\
\hline FTC1A_016 & 0.27 & 0.06 & 0.93 & 10.74 & 1.62 & 574 & 9 & 609 & 20 \\
\hline FTC1A_017 & 0.23 & 0.19 & 0.50 & 1.91 & 1.59 & 2710 & 35 & 2730 & 8 \\
\hline FTC1A_018 & 0.21 & 0.09 & 0.78 & 4.04 & 1.22 & 1424 & 16 & 1443 & 15 \\
\hline FTC1A_019 & 0.20 & 0.10 & 0.48 & 3.68 & 1.07 & 1549 & 15 & 1574 & 9 \\
\hline FTC1A_021 & 0.36 & 0.19 & 0.45 & 1.87 & 1.06 & 2760 & 24 & 2742 & 7 \\
\hline FTC1A_022 & 0.36 & 0.09 & 0.58 & 3.67 & 1.11 & 1553 & 15 & 1470 & 11 \\
\hline FTC1A_023 & 0.35 & 0.08 & 0.77 & 4.55 & 1.26 & 1281 & 15 & 1275 & 15 \\
\hline FTC1A_024 & 0.34 & 0.09 & 0.54 & 4.02 & 1.16 & 1431 & 15 & 1442 & 10 \\
\hline FTC1a_025b & 0.40 & 0.19 & 0.46 & 1.92 & 1.07 & 2700 & 23 & 2711 & 8 \\
\hline FTC1a_026 & 0.39 & 0.07 & 0.57 & 5.77 & 1.11 & 1030 & 11 & 1053 & 12 \\
\hline FTC1a_027 & 0.39 & 0.09 & 0.60 & 3.91 & 1.90 & 1470 & 25 & 1463 & 11 \\
\hline FTC1a_028 & 0.39 & 0.09 & 0.51 & 3.86 & 1.89 & 1485 & 25 & 1445 & 10 \\
\hline FTC1a_030 & 0.39 & 0.11 & 0.63 & 2.86 & 1.96 & 1934 & 33 & 1879 & 11 \\
\hline FTC1a_031 & 0.39 & 0.09 & 0.49 & 3.90 & 1.89 & 1473 & 25 & 1483 & 9 \\
\hline FTC1a_032 & 0.39 & 0.08 & 1.41 & 4.97 & 2.37 & 1182 & 26 & 1176 & 28 \\
\hline FTC1a_033 & 0.39 & 0.09 & 0.64 & 4.41 & 1.93 & 1318 & 23 & 1350 & 12 \\
\hline FTC1a_034 & 0.39 & 0.11 & 0.49 & 2.82 & 1.89 & 1954 & 32 & 1854 & 9 \\
\hline
\end{tabular}

only included analyses w 


\begin{tabular}{|c|c|c|c|c|c|c|c|c|c|}
\hline FTC1a_035 & 0.39 & 0.19 & 0.57 & 1.86 & 1.97 & 2778 & 44 & 2714 & 9 \\
\hline FTC1a_036 & 0.39 & 0.07 & 0.89 & 5.90 & 2.06 & 1010 & 19 & 1012 & 18 \\
\hline FTC1a_037 & 0.39 & 0.10 & 0.61 & 3.44 & 1.95 & 1646 & 28 & 1638 & 11 \\
\hline FTC1a_037b & 0.27 & 0.10 & 0.64 & 3.44 & 1.09 & 1643 & 16 & 1646 & 12 \\
\hline FTC1a_038 & 0.39 & 0.07 & 0.66 & 5.87 & 1.95 & 1014 & 18 & 1010 & 13 \\
\hline FTC1a_039 & 0.40 & 0.08 & 0.61 & 4.53 & 1.96 & 1286 & 23 & 1277 & 12 \\
\hline FTC1a_040 & 0.33 & 0.08 & 0.73 & 4.84 & 1.97 & 1211 & 22 & 1179 & 14 \\
\hline FTC1a_041 & 0.30 & 0.10 & 0.52 & 3.47 & 1.88 & 1631 & 27 & 1677 & 10 \\
\hline FTC1a_042 & 0.27 & 0.09 & 0.56 & 3.97 & 1.89 & 1449 & 25 & 1516 & 11 \\
\hline FTC1a_043 & 0.25 & 0.10 & 0.55 & 3.55 & 1.89 & 1601 & 27 & 1610 & 10 \\
\hline FTC1a_045 & 0.33 & 0.06 & 0.74 & 13.68 & 1.89 & 455 & 8 & 485 & 16 \\
\hline FTC1a_047 & 0.27 & 0.08 & 0.52 & 5.30 & 1.90 & 1113 & 19 & 1173 & 10 \\
\hline FTC1a_048 & 0.23 & 0.08 & 0.63 & 4.72 & 1.95 & 1239 & 22 & 1308 & 12 \\
\hline FTC1a_049 & 0.21 & 0.10 & 0.57 & 3.64 & 1.89 & 1563 & 26 & 1582 & 11 \\
\hline FTC1a_049b & 0.27 & 0.10 & 0.61 & 3.23 & 0.96 & 1740 & 15 & 1653 & 11 \\
\hline FTC1a_050 & 0.20 & 0.07 & 0.63 & 5.64 & 1.91 & 1053 & 19 & 1044 & 13 \\
\hline FTC1a_051 & 0.29 & 0.07 & 0.74 & 5.76 & 1.94 & 1031 & 18 & 1039 & 15 \\
\hline FTC1a_052 & 0.36 & 0.08 & 0.70 & 5.90 & 1.90 & 1009 & 18 & 1102 & 14 \\
\hline FTC1a_053 & 0.36 & 0.08 & 0.82 & 4.91 & 1.98 & 1194 & 22 & 1195 & 16 \\
\hline FTC1a_054 & 0.35 & 0.13 & 0.56 & 2.69 & 1.93 & 2041 & 34 & 2046 & 10 \\
\hline FTC1a_055 & 0.34 & 0.08 & 1.15 & 5.20 & 2.21 & 1135 & 23 & 1102 & 23 \\
\hline FTC1a_056 & 0.40 & 0.09 & 0.91 & 4.23 & 2.33 & 1368 & 29 & 1412 & 17 \\
\hline FTC1a_057 & 0.39 & 0.07 & 0.81 & 5.50 & 2.36 & 1077 & 23 & 1065 & 16 \\
\hline FTC1a_058 & 0.39 & 0.18 & 0.71 & 1.90 & 2.28 & 2726 & 50 & 2638 & 12 \\
\hline FTC1a_059 & 0.40 & 0.10 & 0.76 & 3.55 & 2.29 & 1600 & 32 & 1596 & 14 \\
\hline FTC1a_060 & 0.33 & 0.08 & 0.89 & 5.25 & 2.30 & 1125 & 24 & 1149 & 17 \\
\hline FTC1a_061 & 0.30 & 0.07 & 0.87 & 5.79 & 2.31 & 1027 & 22 & 1002 & 18 \\
\hline FTC1a_063 & 0.25 & 0.09 & 0.73 & 3.93 & 2.27 & 1461 & 30 & 1463 & 14 \\
\hline FTC1a_064 & 0.23 & 0.08 & 1.08 & 5.50 & 2.37 & 1076 & 23 & 1117 & 21 \\
\hline FTC1a_065 & 0.33 & 0.08 & 1.34 & 5.36 & 2.60 & 1102 & 26 & 1180 & 26 \\
\hline FTC1a_066 & 0.27 & 0.08 & 0.77 & 5.79 & 2.28 & 1027 & 22 & 1076 & 15 \\
\hline FTC1a_067 & 0.23 & 0.09 & 0.94 & 3.70 & 2.37 & 1542 & 32 & 1484 & 18 \\
\hline FTC1a_068 & 0.21 & 0.07 & 0.93 & 6.17 & 2.33 & 969 & 21 & 975 & 19 \\
\hline FTC1a_069 & 0.20 & 0.10 & 0.77 & 3.32 & 2.29 & 1697 & 34 & 1652 & 14 \\
\hline
\end{tabular}




\begin{tabular}{|c|c|c|c|c|c|c|c|c|c|}
\hline FTC1a_071 & 0.36 & 0.08 & 0.96 & 5.58 & 2.30 & 1062 & 22 & 1081 & 19 \\
\hline FTC1a_073 & 0.35 & 0.18 & 0.55 & 1.90 & 2.26 & 2723 & 50 & 2688 & 9 \\
\hline FTC1a_074 & 0.34 & 0.09 & 0.86 & 3.80 & 2.37 & 1507 & 32 & 1488 & 16 \\
\hline FTC1A_075 & 0.40 & 0.08 & 0.71 & 5.19 & 2.31 & 1137 & 24 & 1159 & 14 \\
\hline FTC1A_077 & 0.39 & 0.18 & 0.53 & 2.15 & 2.25 & 2458 & 46 & 2659 & 9 \\
\hline FTC1A_079 & 0.33 & 0.09 & 0.99 & 3.79 & 2.45 & 1510 & 33 & 1410 & 19 \\
\hline FTC1A_081 & 0.27 & 0.08 & 0.79 & 4.81 & 2.29 & 1219 & 25 & 1166 & 16 \\
\hline FTC1A_082 & 0.25 & 0.07 & 0.68 & 5.94 & 2.27 & 1004 & 21 & 1006 & 14 \\
\hline FTC1A_083 & 0.23 & 0.08 & 0.92 & 5.21 & 2.35 & 1132 & 24 & 1104 & 18 \\
\hline FTC1A_084 & 0.33 & 0.10 & 0.66 & 3.38 & 2.28 & 1669 & 34 & 1656 & 12 \\
\hline FTC1A_085 & 0.23 & 0.12 & 0.67 & 2.85 & 2.30 & 1937 & 38 & 1900 & 12 \\
\hline FTC1A_086 & 0.21 & 0.07 & 1.20 & 5.86 & 2.44 & 1015 & 23 & 973 & 24 \\
\hline FTC1A_088 & 0.29 & 0.18 & 0.73 & 1.91 & 1.38 & 2709 & 30 & 2689 & 12 \\
\hline FTC1A_089 & 0.36 & 0.09 & 0.78 & 3.67 & 1.17 & 1555 & 16 & 1454 & 15 \\
\hline FTC1a_090 & 0.36 & 0.07 & 1.11 & 5.52 & 1.35 & 1073 & 13 & 1050 & 22 \\
\hline FTC1a_091 & 0.35 & 0.08 & 0.85 & 5.33 & 1.18 & 1108 & 12 & 1119 & 17 \\
\hline FTC1a_092 & 0.34 & 0.08 & 0.93 & 5.13 & 1.27 & 1148 & 13 & 1123 & 18 \\
\hline FTC1a_093 & 0.40 & 0.08 & 0.74 & 4.64 & 1.21 & 1258 & 14 & 1275 & 14 \\
\hline FTC1a_095 & 0.39 & 0.08 & 0.91 & 5.20 & 1.29 & 1134 & 13 & 1110 & 18 \\
\hline FTC1a_096 & 0.39 & 0.08 & 0.96 & 4.98 & 1.34 & 1180 & 14 & 1132 & 19 \\
\hline FTC1a_097 & 0.40 & 0.09 & 0.72 & 4.04 & 1.23 & 1427 & 16 & 1456 & 14 \\
\hline FTC1a_098 & 0.33 & 0.11 & 0.73 & 3.54 & 1.16 & 1606 & 16 & 1724 & 13 \\
\hline FTC1a_100 & 0.30 & 0.10 & 0.96 & 3.26 & 1.41 & 1725 & 21 & 1674 & 18 \\
\hline FTC1a_101 & 0.27 & 0.08 & 0.87 & 5.09 & 1.26 & 1156 & 13 & 1076 & 17 \\
\hline FTC1a_102 & 0.25 & 0.18 & 0.71 & 1.82 & 1.18 & 2820 & 27 & 2696 & 12 \\
\hline FTC1a_103 & 0.23 & 0.07 & 0.81 & 5.44 & 1.21 & 1088 & 12 & 1049 & 16 \\
\hline FTC1a_104 & 0.33 & 0.09 & 0.74 & 3.97 & 1.24 & 1449 & 16 & 1448 & 14 \\
\hline FTC1a_105 & 0.27 & 0.09 & 0.75 & 3.93 & 1.15 & 1461 & 15 & 1453 & 14 \\
\hline FTC1a_106 & 0.23 & 0.09 & 0.98 & 4.29 & 1.38 & 1352 & 17 & 1343 & 19 \\
\hline FTC1a_108 & 0.20 & 0.09 & 0.83 & 4.22 & 1.38 & 1372 & 17 & 1339 & 16 \\
\hline FTC1a_109 & 0.29 & 0.08 & 1.13 & 4.81 & 2.21 & 1217 & 24 & 1148 & 22 \\
\hline FTC1a_110 & 0.36 & 0.11 & 0.86 & 3.02 & 1.94 & 1844 & 31 & 1759 & 16 \\
\hline FTC1a_111 & 0.36 & 0.09 & 0.96 & 4.06 & 1.44 & 1419 & 18 & 1394 & 18 \\
\hline FTC1a_112 & 0.35 & 0.07 & 0.85 & 5.49 & 1.49 & 1079 & 15 & 1046 & 17 \\
\hline
\end{tabular}




\begin{tabular}{|l|l|l|l|l|l|l|l|l|l|}
\hline FTC1a_114 & 0.40 & 0.08 & 0.92 & 4.98 & 1.34 & 1179 & 14 & 1178 & 18 \\
\hline FTC1a_115 & 0.39 & 0.19 & 0.73 & 1.84 & 1.33 & 2799 & 30 & 2701 & 12 \\
\hline FTC1a_116 & 0.39 & 0.09 & 0.87 & 4.10 & 1.39 & 1407 & 18 & 1426 & 16 \\
\hline FTC1a_118 & 0.37 & 0.09 & 0.72 & 3.79 & 1.18 & 1510 & 16 & 1436 & 14 \\
\hline
\end{tabular}


here age is $<10 \%$ discordant 
Supplementary Table 5

Percentage of grains from bedrock samples within each age group raw and adjusted by zircon fertility factor (ZFF)

\begin{tabular}{cccccccccccc}
\hline & raw & \multicolumn{1}{c}{ adjusted } \\
\hline Age (Ma) & I & E & S & P & M & ZFF & I & E & S & P & M \\
\hline$<\mathbf{9 0}$ & $12 \%$ & $8 \%$ & $16 \%$ & $9 \%$ & $17 \%$ & 1 & $19 \%$ & $12 \%$ & $32 \%$ & $16 \%$ & $38 \%$ \\
$\mathbf{9 5 0 - 1 3 0 0}$ & $39 \%$ & $36 \%$ & $59 \%$ & $47 \%$ & $70 \%$ & 3.5 & $18 \%$ & $16 \%$ & $34 \%$ & $23 \%$ & $44 \%$ \\
$\mathbf{1 3 0 0 - 1 6 0 0}$ & $17 \%$ & $17 \%$ & $14 \%$ & $14 \%$ & $10 \%$ & 2.5 & $11 \%$ & $11 \%$ & $11 \%$ & $10 \%$ & $9 \%$ \\
$\mathbf{1 6 0 0 - 1 7 0 0}$ & $13 \%$ & $15 \%$ & $3 \%$ & $10 \%$ & $1 \%$ & 1 & $21 \%$ & $23 \%$ & $6 \%$ & $17 \%$ & $2 \%$ \\
$\mathbf{1 7 0 0 - 1 8 0 0}$ & $8 \%$ & $5 \%$ & $6 \%$ & $5 \%$ & $1 \%$ & 1 & $13 \%$ & $8 \%$ & $12 \%$ & $9 \%$ & $2 \%$ \\
$\mathbf{1 8 0 0 - 1 9 0 0}$ & $4 \%$ & $6 \%$ & $2 \%$ & $8 \%$ & 0 & 1 & $6 \%$ & $9 \%$ & $4 \%$ & $14 \%$ & 0 \\
$\mathbf{1 9 0 0 - 2 5 0 0}$ & $2 \%$ & $2 \%$ & 0 & 0 & $1 \%$ & 1 & $3 \%$ & $3 \%$ & 0 & 0 & $2 \%$ \\
$>\mathbf{2 5 0 0}$ & $6 \%$ & $11 \%$ & 0 & $7 \%$ & $1 \%$ & 1 & $10 \%$ & $17 \%$ & 0 & $12 \%$ & $2 \%$ \\
\hline
\end{tabular}

$\mathrm{I}=$ Ionia Formation (Dickinson et al., 2010); $\mathrm{E}=$ Eaton Sandstone, $\mathrm{S}=$ Saginaw Formation, $\mathrm{P}=$ Parma Sandstone, $M=$ Marshall Sandstone (Boothroyd, 2012) 
Supplementary Table 6

Results of statistical comparison between the bedrock samples and till samples.

K-S Test

\begin{tabular}{lllll}
\hline & $\mathrm{HEL}$ & $\mathrm{SL}$ & $\mathrm{LML}$ & $\mathrm{UN}$ \\
\hline Ionia & 0.021 & 0.168 & 0.013 & 0.395 \\
Eaton & 0.002 & 0.014 & 0.036 & 0.555 \\
Saginaw & 0.000 & 0.004 & 0.000 & 0.000 \\
Parma & 0.000 & 0.005 & 0.000 & 0.013 \\
Marshall & 0.000 & 0.000 & 0.000 & 0.000 \\
\hline
\end{tabular}

Degree of likeness

\begin{tabular}{lllll}
\hline & $\mathrm{HEL}$ & $\mathrm{SL}$ & $\mathrm{LML}$ & $\mathrm{UN}$ \\
\hline lonia & $36.9 \%$ & $43.4 \%$ & $36.8 \%$ & $40.3 \%$ \\
Eaton & $35 \%$ & $41.5 \%$ & $34.7 \%$ & $37.6 \%$ \\
Saginaw & $52.1 \%$ & $58.1 \%$ & $50.8 \%$ & $60.5 \%$ \\
Parma & $36.1 \%$ & $42.3 \%$ & $36.1 \%$ & $46.3 \%$ \\
Marshall & $39.9 \%$ & $51.1 \%$ & $40.0 \%$ & $51.3 \%$ \\
\hline
\end{tabular}

Degree of overlap

\begin{tabular}{lllll}
\hline & $\mathrm{HEL}$ & $\mathrm{SL}$ & $\mathrm{LML}$ & $\mathrm{UN}$ \\
\hline Ionia & 0.407 & 0.504 & 0.440 & 0.439 \\
Eaton & 0.414 & 0.513 & 0.447 & 0.446 \\
Saginaw & 0.520 & 0.635 & 0.559 & 0.555 \\
Parma & 0.412 & 0.511 & 0.445 & 0.444 \\
Marshall & 0.346 & 0.433 & 0.375 & 0.375 \\
\hline
\end{tabular}

Degree of similarity

\begin{tabular}{lllll}
\hline & $\mathrm{HEL}$ & $\mathrm{SL}$ & $\mathrm{LML}$ & $\mathrm{UN}$ \\
\hline Ionia & 0.557 & 0.616 & 0.555 & 0.587 \\
Eaton & 0.546 & 0.599 & 0.540 & 0.575 \\
Saginaw & 0.704 & 0.762 & 0.693 & 0.757 \\
Parma & 0.554 & 0.620 & 0.552 & 0.629 \\
Marshall & 0.616 & 0.709 & 0.653 & 0.715 \\
\hline
\end{tabular}

